\title{
Two new subterranean Parastenocarididae (Crustacea, Copepoda, Harpacticoida) from Western Australia
}

\author{
T. Karanovic \\ Western Australian Museum, Locked Bag 49, Welshpool DC, Western Australia 6986, Australia \\ E-mail: karanovic@museum.wa.gov.au
}

\begin{abstract}
Two new species of the genus Parastenocaris Kessler, 1913 are described from Australian subterranean waters, both based upon males and females. Parastenocaris eberhardi sp. nov. has been found in two small caves in southwestern Western Australia. It belongs to the "minuta"-group of species, having five large spinules at base of the fourth leg endopod in male. The integumental window pattern of $P$. eberhardi is the same as for the first reported Australian representative ( $P$. solitaria), which helps to establish its affinities too, since only females of the latter species were described. Parastenocaris eberhardi has a clear Eastern Gondwana connection, like many other Australian copepods of freshwater origins. Parastenocaris kimberleyensis $\mathrm{sp}$. nov. is described from a single water-monitoring bore in the Kimberley district, northeastern Western Australia. It belongs to the "brevipes"-group of species, for which a key to world species is given. The present state of systematics within the family Parastenocarididae is briefly discussed.
\end{abstract}

\section{INTRODUCTION}

Until relatively recently the groundwater fauna of Australia was very poorly known (Marmonier $e t$ al. 1993), and that mostly from the investigation of cave faunas in the eastern portion of the continent (Thurgate et al. 2001a; 2001b). Western Australia has been considered to have poor prospects for supporting subterranean faunas, owing to the lack of water and low nutrient input from xeric plant communities (Moore 1964; Hamilton-Smith 1967; Barr 1973; Howarth 1980). Knowledge of this region, however, has developed substantially in the last decade, such that it is now recognized to include one of the world's most diverse and notable subterranean faunas (Holthuis 1960; Poore and Humphreys 1992, 1998; Wilson and Ponder 1992; Bartsch 1993; Humphreys 1993a, 1993b, 1993c, 2000, 2001; Bruce and Humphreys, 1993; Harvey et al. 1993; Aubrecht and Kozur 1995; Baltanas and Danielopol 1995; Yager and Humphreys 1996; Bradbury and Williams 1996a, 1996b, 1997a, 1997b; Harvey 1998; Knott and Halse 1999; Bradbury 2000, 2002; Watts and Humphreys 2000, 2001, 2003; Moore et al. 2001; Karanovic and Marmonier 2002, 2003). Recently, a number of stygal copepods have been described from ancient freshwater habitats (Pesce et al. 1996a; Pesce and De Laurentiis 1996; De Laurentiis et al. 1999, 2001; Karanovic 2003, 2004), as well as anchialine waters (Pesce et al. 1996b; Jaume and Humphreys 2001; Jaume et al. 2001; Karanovic et al. 2001; Lee and Huys 2002; Karanovic and Pesce 2002).

The family Parastenocarididae Chappuis, 1940 is almost exclusively freshwater in distribution (Boxshall and Jaume 2000) and has six well recognized genera: Parastenocaris Kessler, 1913; Forficatocaris Jakobi, 1969; Paraforficatocaris Jakobi, 1972; Potamocaris Dussart, 1979; Murunducaris Reid, 1994; and Simplicaris Galassi and De Laurentiis, 2004. Few species have been recorded from slightly brackish environments (Wells 1986), but none from marine littoral or meiofauna. Jakobi (1972) proposed a new system for the family by splitting it into 26 different genera, which was strongly criticized by Schminke (1976) and has not been adopted by Dussart and Defaye (1990) nor any other modern taxonomist. Although the phylogenetic relationships within the Parastenocarididae are still uncertain (Martínez Arbizu 1997), the system of eight phyletic groups proposed by Lang (1948) seems to be the most appropriate at this time, although it requires knowledge of males, and many species are still known only from females (more precisely, the "proserpina"-group was established by Kunz (1938) and Lang (1948) established the remaining seven groups). Lang's (1948) system was later supplemented by Noodt $(1962,1963,1972)$, but with limited success. While one of Noodt's groups was consequently accepted and elevated to the generic level (Forficatocaris), others (although possibly phylogenetically correct) are morphologically hard to distinguish from previously known groups. However, all these groups are Neotropical and not related to the Australian Parastenocarididae. The genera Forficatocaris, Paraforficatocaris, Potamocaris 
and Murunducaris contain only a few species and are exclusively Neotropical (Reid 1994). Currently, the genus Parastenocaris contains around 220 species and subspecies (Galassi and De Laurentiis 2004), although some of them are very inadequately described. Representatives of this genus are distributed over all continents, although, interestingly they have never been recorded in New Zealand (Huys and Boxshall 1991). Recently, Ranga Reddy (2001) reported the first Parastenocarididae from the Indian subcontinent (three new species of Parastenocaris), hardly surprising considering more than 20 species already known from Asia, including six of them from Sri Lanka (Enckell 1970). The taxonomic impediments surrounding the genus Parastenocaris was recently discussed by Galassi and De Laurentiis (2004), who also proposed a list of phylogenetically informative characters for this genus an the family as a whole. They also followed Reid's (1994) rejection of the Chappuis's (1933) description of the family as unavailable "until a cursory diagnosis was eventually supplied (Chappuis 1940)". Although this sounds taxonomically relatively just, it should be pointed out that Reid (1994), or any other author before 2000, did not expressly applied Article 13 of the then current edition of the ICZN Code and, therefore, is not completely satisfying Article 13.2.1 now (see ICZN 1999).

Parastenocaris solitaria Karanovic, 2004 is the only other representative of the family Parastenocarididae described from the Australian continent. It is known only from females, so its affinities could not be properly evaluated (Karanovic 2004). Schminke (1981) reported "four species belonging to three genera" of Parastenocarididae from Australia, but unfortunately they all remain undescribed and unnamed. In this paper two new Australian species of Parastenocaris are described, luckily based on both females and males. One of these is morphologically very similar to $P$. solitaria, which helps to establish the affinities of the latter, while the other belongs to a different group of species.

\section{MATERIAL AND METHODS}

The sample from the Kimberley district was collected by a haul-net (mesh size 250 micrometers) from a water monitoring bore. Haul-nets are simple plankton nets of different sizes suitable for the borehole, which can range from 30 to $180 \mathrm{~mm}$ in diameter. A weighted net was lowered down the borehole with a bottle screwed to its distal end, then hauled through the water column several times. The sample was sorted live under a dissecting microscope and the copepods picked out and fixed in $70 \%$ ethanol and assigned a field number (prefix
BES). Samples from the Margaret River caves were collected with a hand net, directly from the water body, or by washing tree roots and interstitial sand. Those samples were also assigned field numbers (prefix $\mathrm{CW}$ ). Specimens were dissected and mounted on microscope slides in Faure's medium, which was prepared following the procedure discussed by Stock and Von Vaupel Klein (1996), and dissected appendages were then covered with a coverslip. For the urosome or the entire animal two human hairs were mounted between the slide and coverslip, so the parts could not be compressed. By manipulating the coverslip carefully by hand, the whole animal or a particular appendage could be positioned in different aspects, making possible the observation of morphological details. During examination water slowly evaporated, and appendages eventually remained in completely dry Faure's medium. All material has been deposited in the Western Australian Museum, Perth (WAM). Except for the abbreviations mentioned above and connected to the materials assignation, no others have been used. All drawings were prepared using a drawing tube attached to a Leica-DMLS brightfield compound microscope, with C-PLAN achromatic objectives. Morphological terminology follows Huys and Boxshall (1991), except for small differences in the spelling of some appendages (antennula, mandibula, maxillula instead of antennule, mandible, maxillule), as an attempt to standardize the terminology for homologue appendages in different groups of crustaceans.

\section{SYSTEMATICS}

\section{Order Harpacticoida Sars, 1903}

Family Parastenocarididae Chappuis, 1940

Genus Parastenocaris Kessler, 1913

Parastenocaris eberhardi sp. nov. Figures 1-33

\section{Material examined}

\section{Holotype}

Female (WAM C28618), Western Australia, Margaret River Region, Strongs Cave, monitoring well, interstitial with tree roots, 6 July 2002, leg. S. Eberhard, $34^{\circ} 08^{\prime} 40^{\prime \prime S} 115^{\circ} 03^{\prime} 45^{\prime \prime} \mathrm{E}$ (CW00265): dissected on 1 slide.

\section{Allotype}

Male (WAM C28619), Western Australia, Margaret River Region, Strongs Cave, monitoring well, interstitial with tree roots, 6 July 2002, leg. S.

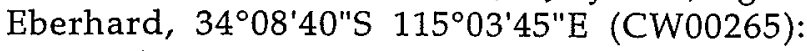
dissected on 1 slide. 


\section{Other paratypes}

Western Australia, Margaret River Region, Strongs Cave, monitoring well, interstitial with tree roots, 6 July 2002, leg. S. Eberhard, $34^{\circ} 08^{\prime} 40^{\prime \prime} S$ $115^{\circ} 03^{\prime} 45^{\prime \prime} \mathrm{E}$ (CW00265): 1 female in alcohol (WAM C28620).

\section{Other material}

Western Australia, Margaret River Region, Kudjal Yolgah Cave, root mat in a deep stream, 23 June

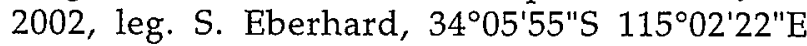
(CW00270): 1 female dissected on 1 slide (WAM C28621).

\section{Description}

\section{Female (holotype)}

Total body length, measured from tip of rostrum to posterior margin of caudal rami (excluding caudal setae), $374 \mu \mathrm{m}$. Preserved specimen colourless. Nauplius eye absent. Habitus (Figures 1 and 2) cylindrical and very slender, without demarcation between prosome and urosome; prosome/urosome ratio 0.8 ; greatest width very hard to locate. Body length/width ratio about 9.3; cephalothorax about 1.1 times as wide as genital double-somite. Free pedigerous somites without expansions laterally or dorsally. Integument not strongly chitinized, covered with minute pits (except cephalothorax, caudal rami and appendages), pattern becoming more dense towards posterior end of body; integumental windows on third and fourth urosomites (fourth and fifth urosomites, if second and third would not be fused into genital double-somite) laterally and on cephalothorax dorsally. Rostrum small, membranous, linguiform, reaching middle of first antennular segment, about as long as wide and not demarcated at base; with 2 dorsal sensilla. Cephalothorax about 1.9 times as long as wide; equaling $20 \%$ of total body length. Surface of dorsal shield covering cephalothorax with several very long sensilla and with large integumental window dorsally, inside which additional small area with even thinner integument visible. Tergites of 3 free pedigerous somites also with few large sensilla, but without integumental windows. Hyaline fringes of all somites smooth, except preanal somite, which hyaline fringe finely serrated both dorsally and ventrally. Genital double-somite (Figures 16 and 17) about as long as wide (ventral view), without any trace of subdivision, ornamented just with pair of median sensilla dorsally and 6 posterior sensilla (2 dorsal, 2 ventral and 2 lateral). Genital complex occupying anterior ventral half of genital doublesomite. Genital apertures paired, each closed off by small, unarmed operculum derived from vestigial sixth leg. Median copulatory pore located anteriorly between genital apertures (Figure 16). Seminal receptacles not discernable.Third urosomite ornamented with 6 long posterior sensilla (2 dorsal, 2 ventral and 2 lateral) and with 2 lateral cuticular windows (no ventral groups of large spinules at middle). Preanal somite without surface ornamentation, with 2 lateral cuticular windows similar to those on previous somite (Figures 16 and 17). Anal somite with pair of large dorsal sensilla and pair of lateral ( 1 on each side) cuticular pores in proximal half. Anal operculum (Figure 1) with almost straight posterior margin, smooth, not reaching posterior end of anal somite and representing $71 \%$ of somite's width. Anal sinus smooth.

Caudal rami (Figures 10, 11 and 16) relatively long, semicylindrical (with greatest width at $3 / 5$ of ramus length), divergent, with space between them about twice width of ramus, and about 2.9 times as long as greatest width (ventral view); unornamented and armed with 7 armature elements ( 3 lateral, 1 dorsal and 3 apical). Dorsal seta relatively long, inserted slightly closer to inner margin at about $3 / 5$ of ramus length, about 1.5 times as long as caudal ramus, biarticulate at base and smooth. Lateral setae thin and smooth, all shorter than ramus, inserted close to each other slightly posterior to dorsal seta. Inner apical seta smooth, slightly shorter than ramus. Middle apical seta strongest, without breaking plane, smooth, about 2.5 times as long as outer apical seta, and 0.3 times as long as whole body. Outer apical seta also without breaking plane, but pinnate along outer margin.

Antennula (Figure 3) 7-segmented, unornamented, approximately as long as cephalothorax, with broad aesthetasc on fourth segment not reaching beyond tip of appendage; more slender apical aesthetasc on seventh segment fused basally to apical seta; setal formula as follows: 0.4.4.1.1.0.9. Proximalmost seta on second segment unipinnate and articulating on basal part; all other setae smooth and without breaking plane or articulation. Length ratio of antennular segments, from proximal end, $1: 3: 1.3: 1.4: 0.7: 0.8: 1.4$.

Antenna (Figure 4) short and robust, composed of coxa, allobasis, 1-segmented endopod, and 1segmented exopod. Coxa small, unornamented. Allobasis about 2.8 times as long as wide, unarmed, and ornamented with 2 bunches of spinules on anterior surface. Endopod about 2.7 times as long as wide, with surface frill subdistally, ornamented with few long spinules along anterior surface, armed laterally with 2 spines and apically with 5 strong armature elements (2 of which geniculate). Exopod minute, cylindrical, about 3 times as long as wide, unornamented, armed with only 1 apical bipinnate seta, about 2.5 times as long as segment.

Mandibula (Figure 6) with narrow cutting edge on elongated coxa, armed with 3 coarse teeth 


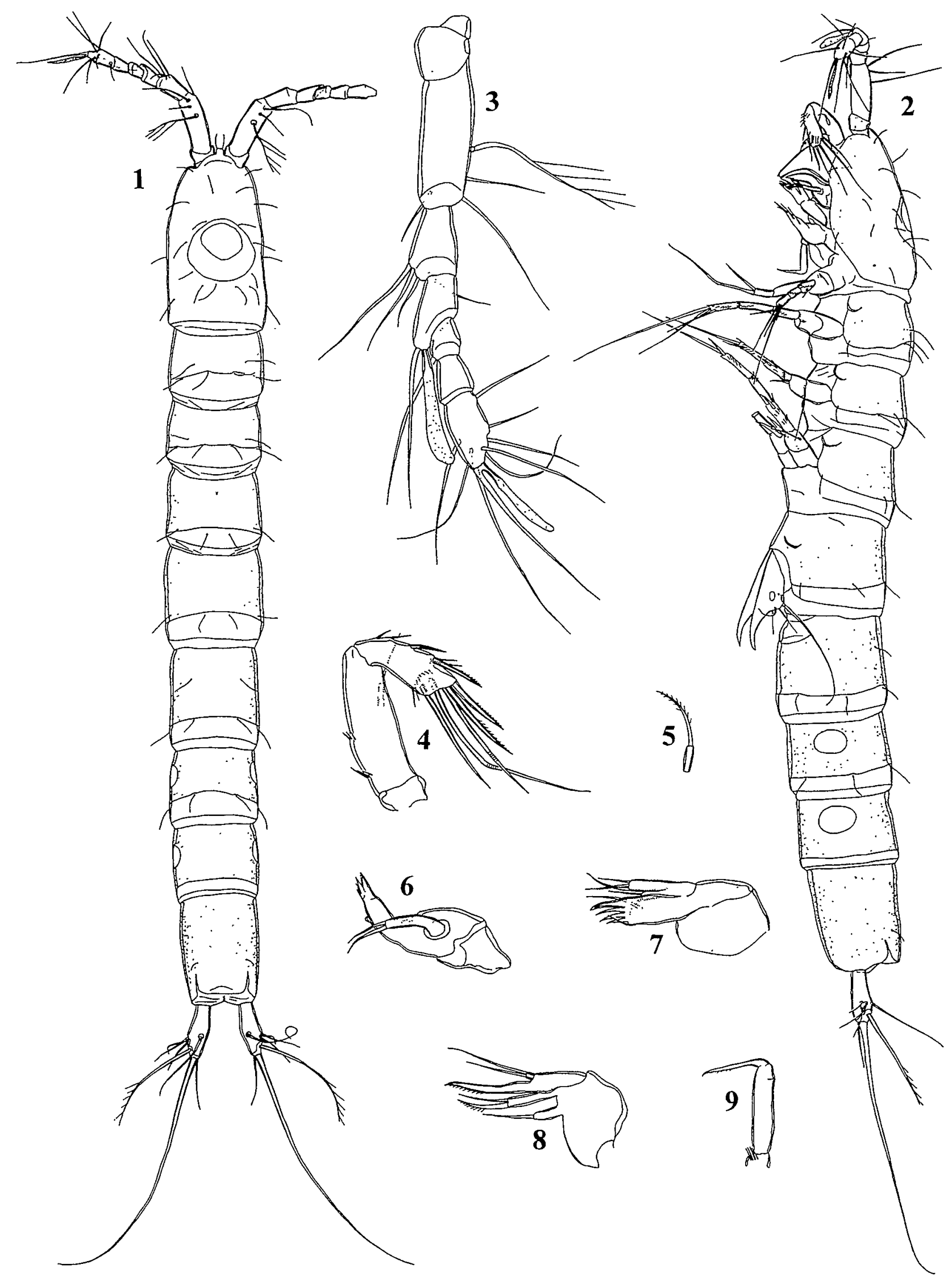

\section{1,2}

$3,4,5,6,7,8,9$

Figures 1-9 Parastenocaris eberhardi sp. nov., holotype (female): 1, habitus, dorsal view; 2, habitus, lateral view; 3 , antennula; 4, antenna; 5 , exopod of antenna; 6, mandibula; 7, maxillula; 8 , maxilla; 9 , maxilliped. Scales = $0.1 \mathrm{~mm}$. 


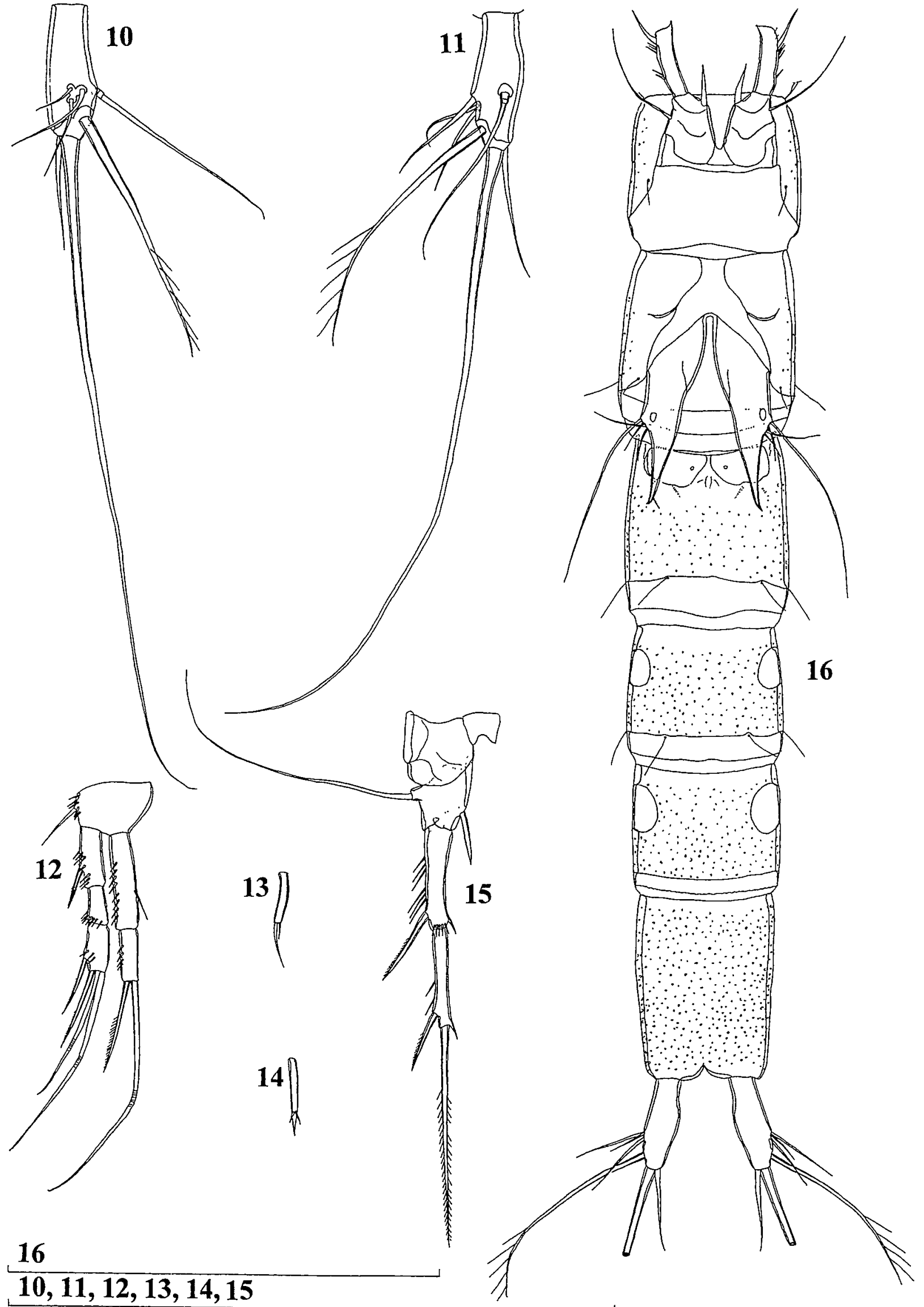

Figures 10-16 Parastenocaris eberhardi sp. nov., holotype (female): 10, left caudal ramus, lateral view; 11, left caudal ramus, dorsal view; 12, first swimming leg; 13, endopod of second swimming leg; 14, endopod of fourth swimming leg; 15, third swimming leg; 16, third free pedigerous somite and urosome, ventral view. Scales $=0.1 \mathrm{~mm}$. 
ventrally, 1 smooth seta dorsally, and several smaller teeth in between. Palp 1-segmented, cylindrical, about 4 times as long as wide, unornamented, and armed apically with 2 smooth subequal setae.

Maxillula (Figure 7) with large praecoxa, its arthrite rectangular, long, unornamented, and armed with 1 strong anterior surface setae, 1 lateral and 4 apical elements (probably 3 spines and 1 strong seta). Coxal endite small, armed with 2 smooth armature elements of about same length. Basis longer than coxal endite, armed with 3naked setae apically. Endopod and exopod completely reduced.

Maxilla (Figure 8) with 2 endites on syncoxa; proximal one armed apically with only 1 bare seta; distal endite twice as long as proximal one, with naked seta and 1 pinnate spine. Basis drawn out into strong claw, without seta at base. Endopod represented by minute but distinct segment, with 2 bare subequal apical setae.

Maxilliped (Figure 9) with short syncoxa, ornamented with transverse row of long spinules; basis about 4 times as long as wide, unornamented and unarmed; endopod represented by distally pinnate curved claw, about 0.8 times as long as basis.

First swimming leg (Figure 12) with smooth coxa and intercoxal sclerite. Basis ornamented with few large spinules around insertation of outer spine. Exopod 3-segmented, armed with 1 outer spine on first segment and 4 armature elements on third segment ( 2 outer spines and 2 apical geniculate setae); ornamented with few large spinules along outer margin on all segments. Endopod 2segmented, longer than exopod; first segment reaching slightly beyond distal margin of second exopodal segment, about 4.2 times as long as wide, armed with single smooth seta on inner margin, ornamented with large spinules along outer margin; second segment armed apically with long geniculate seta and much shorter spine.

Second swimming leg with smooth coxa, intercoxal sclerite and basis; basis armed with short outer spine. Exopod 3-segmented, ornamented with large spinules along outer margin, and with hyaline frills on each segment distally on inner side; first segment armed with single outer spine; second segment unarmed, third segment armed with 3 long armature elements (probably outer spine and 2 apical setae). Endopod (Figure 13) 1-segmented, slender, unornamented, reaching to middle of first exopodal segment, armed apically with 2 smooth thin setae; outer seta about 3 times as long as inner one.

Third swimming leg (Figure 15) also with smooth coxa, intercoxal sclerite and basis; basis armed with very long, smooth outer seta, about 1.4 times as long as exopod. Exopod 2-segmented, ornamented with few large spinules along outer margin, both segments with hyaline frills distally on inner side; first segment armed with single outer spine; second segment armed with outer spine and apical strong seta. Endopod 1-segmented, unarmed and unornamented, in form of spiniform process, not reaching middle of first exopodal segment.

Fourth swimming leg with smooth coxa, intercoxal sclerite and basis; basis armed with long smooth outer seta. Exopod 3-segmented, ornamented with few large spinules along outer margin, and second and third segment with hyaline frills distally on inner side; first segment armed with single outer spine; second segment unarmed; third segment armed with outer spine and very long apical seta. Endopod (Figure 14) 1-segmented, in form of spiniform process, reaching $3 / 4$ of first exopodal segment length; ancestral apical spine completely fused to somite, with 2 spinules at its ancestral distinction.

Fifth leg (Figure 18) simple triangular cuticular plate, ornamented with small cuticular pore basally and larger cuticular window; distal part protruding posteriorly as very long, outwardly curved, spiniform process, reaching almost middle of genital double-somite. Armature consists of very long outer basal seta and 3 additional small setae along outer margin.

Sixth leg (Figures 16 and 19) small cuticular plate, covering gonopore, ornamented with single cuticular pore and unarmed.

\section{Male (allotype)}

Body length, excluding caudal setae, $308 \mu \mathrm{m}$. Habitus, ornamentation of prosomal somites, colour and nauplius eye similar to female. Genital and first abdominal somite not fused; genital somite about twice as wide as long; first abdominal (third urosomal) somite ornamented with 2 ventrolateral bunches of 3-4 spinules at middle (Figure 25). Single large, completely formed, longitudinallyplaced spermatophore (Figure 23) visible inside fifth pedigerous and genital somites. Cuticular windows, caudal rami (Figure 25), antenna, mandibula, maxillula, maxilla, maxilliped, first swimming leg (Figure 29) and fifth leg (Figure 25) similar to female.

Antennula (Figures 24 and 33) prehensile, 7segmented, with very strong geniculation between fifth and sixth segment. Proximal anterior corner of fifth segment and distal anterior corner of sixth segment protruding like strong, spiniform processes, forming very powerful pincers. Proximal aesthetasc (in male of fifth segment instead on fourth) much wider than in female, while aesthetasc on apical segment similar to that of female. Setal formula as follows: 0.4.4.2.3.0.9.

Second swimming leg (Figure 30) without seta on outer margin of basis; segment ornamented with 


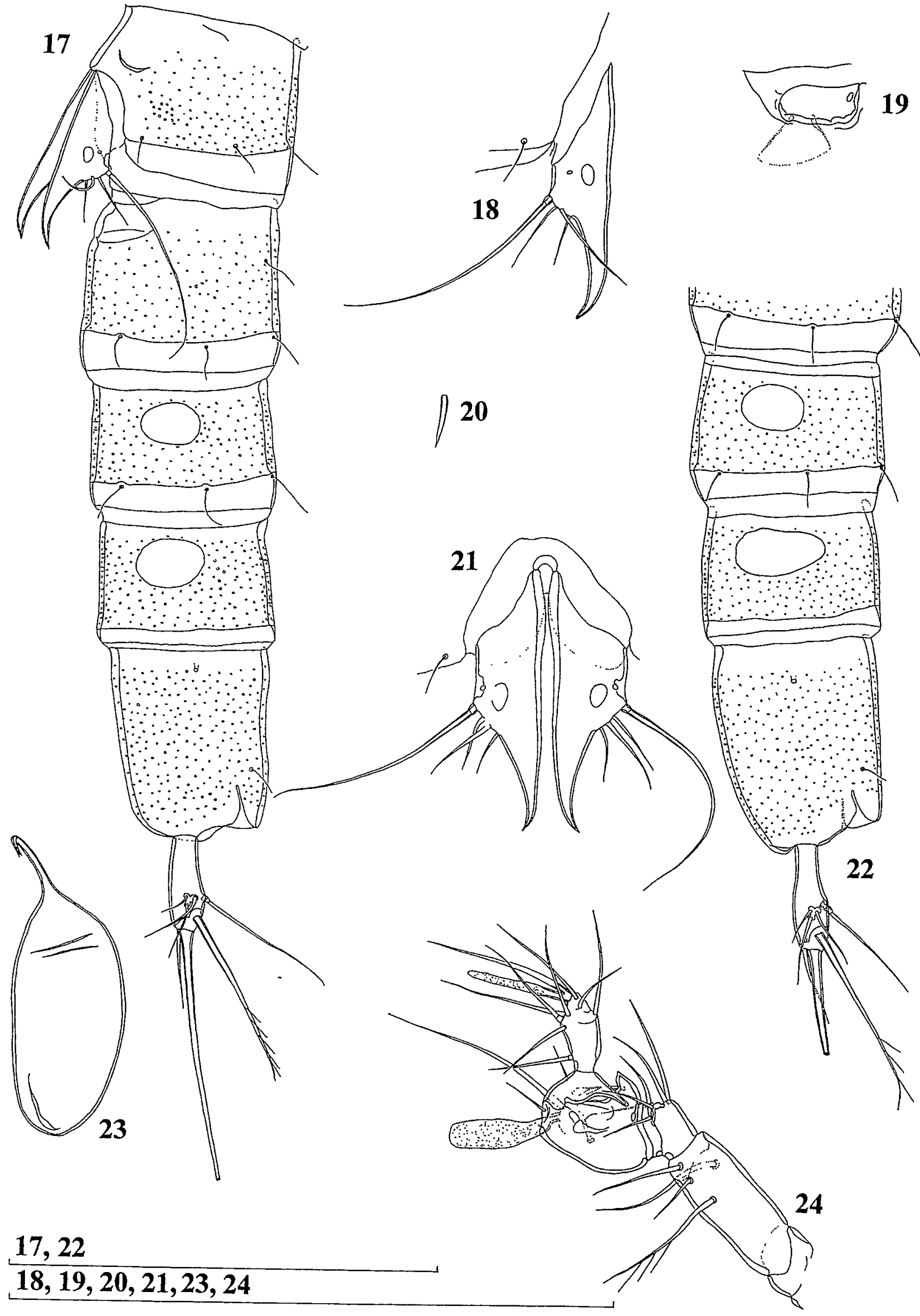

Figures 17-24 Parastenocaris eberhardi sp. nov., 17-19, holotype (female); 20-22, paratype (female); 23 and 24, allotype (male): 17, urosome, lateral view; 18, fifth leg; 19, sixth leg; 20, endopod of third swimming leg; 21, fifth legs; 22 , abdomen, lateral view; 23 , spermatophore; 24 , antennula. Scales $=0.1 \mathrm{~mm}$. 


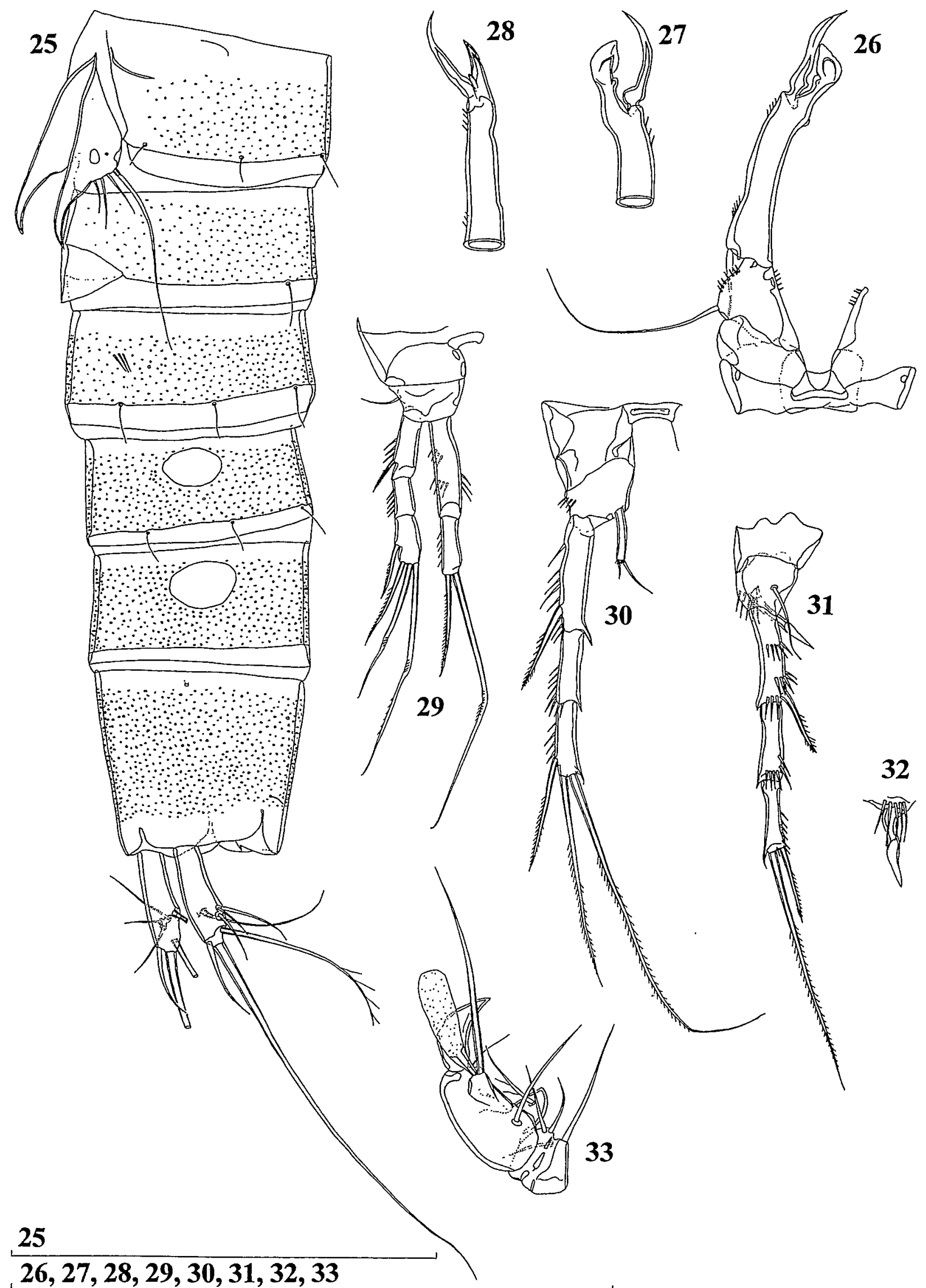

Figures 25-33 Parastenocaris eberhardi sp. nov., allotype (male): 25, urosome, semilateral view; 26, third swimming leg, anterior view; 27, distal part of third swimming leg, semilateral view; 28, distal part of third swimming leg, semiinterior view; 29, first swimming leg; 30, second swimming leg; 31, fourth swimming leg; 32, endopod of fourth swimming leg; 33 , part of antennula. Scales $=0.1 \mathrm{~mm}$. 
several large spinules. Exopod and endopod similar to female.

Third swimming leg (Figures 26, 27 and 28) with smooth praecoxa, coxa and intercoxal sclerite. Basis robust, armed with long outer seta and ornamented with longitudinal row of spinules along distal part of inner margin and diagonal row of spinules close to outer margin. Endopod completely reduced. Exopod with both segments fused; ancestral proximal segment about 3.5 times as long as wide, curved inward, ornamented with 2 short rows of spinules along outer margin, armed subapically with large, smooth, curved and sharp spine, which reaching beyond end of whole exopod; ancestral distal segment (apophysis) small, terminating with outward curved tridimensional structure and forming pincers with armature element of first segment.

Fourth swimming leg (Figure 31) with exopod very similar to female. Endopod (Figure 32) also 1segmented, but unornamented, curved and characteristically modified, with swollen and less sclerotized distal part; 5 large spinules at base of endopod, on inner side of basis.

Sixth leg (Fig 25) simple triangular plate, unarmed and unornamented; both sixth legs distinct at base and with close inner margins, but not fused.

\section{Variability}

Body lengths of females range from $339 \mu \mathrm{m}$ to $383 \mu \mathrm{m}$ ( $365 \mu \mathrm{m}$ average; $\mathrm{n}=3$ ); only one male was collected and studied. Cuticular windows on preanal somite of the paratype female (Figure 22) is larger than in holotype. The same female has somewhat curved endopod of the third swimming leg (Figure 20), as well as slightly shorter setae on the fifth leg (Figure 21).

\section{Etymology}

The species is named in honour of Mr Stefan Eberhard from the "Cave Works" (an ecotourism project of the Augusta Margaret River Tourism Association, Western Australia), who collected the material in which this species has been found.

\section{Distribution}

At present Parastenocaris eberhardi sp. nov. is known only from two caves in the Margaret River Region, southwestern Western Australia (Figure 63).

Parastenocaris kimberleyensis sp. nov. Figures 34-63

\section{Material examined}

Holotype

Male (WAM C28624), Western Australia,
Kimberley Region, Argyle Diamond Mine, monitoring bore 13S, 10 October 2002, leg. W.F. Humphreys and R. Webb, $16^{\circ} 43^{\prime} 18^{\prime \prime S} 128^{\circ} 24^{\prime} 02^{\prime \prime} \mathrm{E}$ (BES: 9697.1): dissected on 2 slides.

\section{Allotype}

Female (WAM C28625), Western Australia, Kimberley Region, Argyle Diamond Mine, monitoring bore 13S, 10 October 2002, leg. W.F. Humphreys and R. Webb, $16^{\circ} 43^{\prime} 18^{\prime \prime} \mathrm{S} 128^{\circ} 24^{\prime} 02^{\prime \prime} \mathrm{E}$ (BES: 9697.1): dissected on 2 slides.

\section{Other paratypes}

Western Australia, Kimberley Region, Argyle Diamond Mine, monitoring bore 13S, 10 October 2002 , leg. W.F. Humphreys and R. Webb, $16^{\circ} 43^{\prime} 18^{\prime \prime} S$ 128 $24^{\prime} 02^{\prime \prime E ~(B E S: ~ 9697.1): ~} 2$ males and 2 copepodids in alcohol (WAM C28626).

\section{Topotype}

Western Australia, Kimberley Region, Argyle Diamond Mine, monitoring bore 13S, 13 October 2002 , leg. W.F. Humphreys and R. Webb, $16^{\circ} 43^{\prime} 18^{\prime \prime S}$ 128 24'02"E (BES: 9752): 1 male, dissected on 1 slide (WAM C28627).

\section{Description}

\section{Male (holotype)}

Total body length, measured from tip of rostrum to posterior margin of caudal rami (excluding caudal setae), $500 \mu \mathrm{m}$. Preserved specimen colourless. Nauplius eye absent. Habitus (Figure 34) cylindrical and very slender, without demarcation between prosome and urosome; prosome/urosome ratio 0.9 ; greatest width at posterior end of cephalothorax, but not very obvious. Body length/ width ratio about 8.3 ; cephalothorax just slightly wider than genital somite. Free pedigerous somites without any expansions laterally or dorsally. Integument very weakly chitinized; integumental windows absent. Rostrum small, membranous, ovoid, reaching middle of first antennular segment, about as long as wide and not demarcated at base; with 2 dorsal sensilla. Cephalothorax about 1.6 times as long as wide; representing $20 \%$ of total body length. Surface of dorsal shield covering cephalothorax ornamented with only few small sensilla. Tergites of free pedigerous somites also ornamented with few small sensilla, except completely smooth first one. Hyaline fringes of all somites smooth. Genital somite ornamented with 2 small sensilla dorsally, about 1.5 times as wide as long, with single, large, completely formed, longitudinally-placed spermatophore (Figures 34 and 35) visible inside. Third and fourth urosomites ornamented with pair of dorsal and ventral spinules each. Fifth urosomal (preanal) somite 


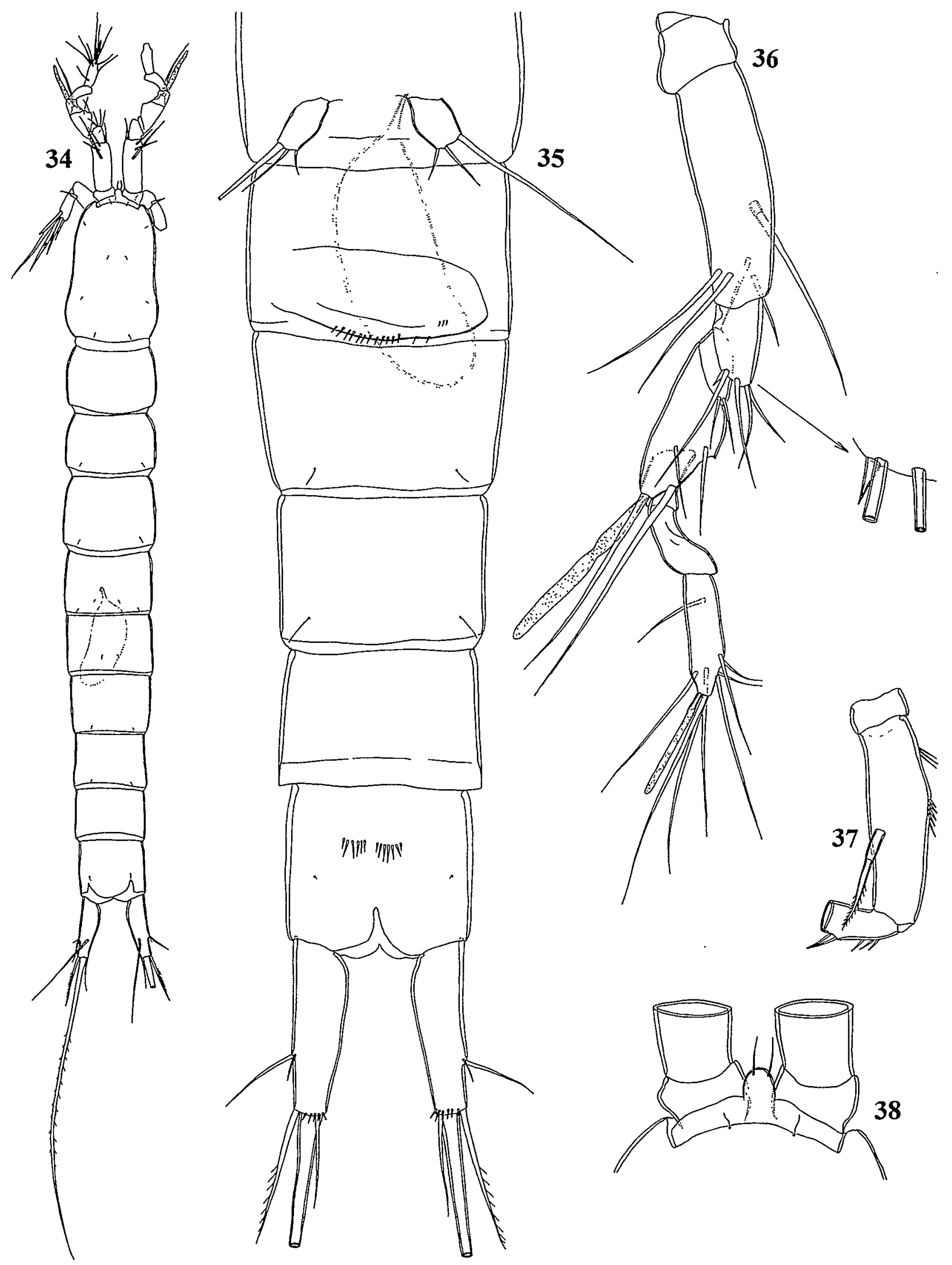

Figures 34-38 Parastenocaris kimberleyensis sp. nov., holotype (male): 34, habitus, dorsal view; 35, urosome, ventral view; 36, antennula, with enlarged detail of third segment armature; 37, antenna, without distal part of endopod; 38 , rostral area, dorsal view. Scales $=0.1 \mathrm{~mm}$. 
without any visible ornamentation. Anal somite ornamented with pair of large dorsal sensilla, 2 ventral cuticular pores, and 2 short ventral rows of spinules at $1 / 3$ of somite length. Anal operculum (Figure 41) strongly convex, smooth, not reaching posterior end of anal somite, representing $63 \%$ of somite's width. Anal sinus smooth.

Caudal rami (Figures 35, 41 and 42) long, cylindrical (slightly narrowing towards distal end), divergent, with space between them about 2 ramus width, and about 3.3 times as long as greatest width (ventral view); armed with 6 armature elements (2 lateral, 1 dorsal and 3 apical). Ornamentation consists of small cuticular pore laterally at anterior part. Dorsal seta relatively long, inserted somewhat closer to inner margin at about $2 / 3$ of ramus length, about 1.3 times as long as caudal ramus, biarticulate at base and smooth. Lateral setae thin and smooth, inserted close to each other at $2 / 3$ of ramus length. Proximal lateral seta placed more dorsally, about 3 times as long as distal one, and about 0.4 times as long as ramus. Inner apical seta small, smooth, about 0.5 times as long as ramus. Middle apical seta strongest, without breaking plane, bipinnate, about 6 times as long as outer apical seta and 0.4 times as long as whole body. Outer apical seta also without breaking plane, unipinnate along outer margin, about 0.8 times as long as ramus.

Antennula (Figures 36 and 44) 8-segmented, prehensile, not strongly geniculate, unornamented, approximately as long as cephalothorax. Broad aesthetasc on fourth segment reaching tip of appendage. Slender and short apical aesthetasc on eighth segment. Setal formula as follows: 0.5.5.2.4.0.0.9. Inner margin of fifth segment protruding into small spiniform process. One of setae on third segment very short, spiniform (Figure 36). All setae smooth and without breaking planes. Only 1 seta on second segment articulating on basal part.

Antenna (Figure 37) relatively slender and long, composed of coxa, allobasis, 1-segmented endopod, and 1-segmented exopod. Coxa small, unornamented. Allobasis about 3.3 times as long as wide, unarmed, and ornamented with 2 short rows of long spinules along anterior surface. Endopod about 2.8 times as long as wide, with surface frill subdistally, ornamented with few large spinules along anterior surface, armed laterally with 2 spines and apically with 5 strong armature elements (2 of which geniculate). Exopod minute, cylindrical, about 3 times as long as wide, unornamented, armed with only 1 bipinnate apical seta, about 2.3 times as long as segment.

Mandibula (Figure 39) with narrow cutting edge on elongated coxa, armed with 3 coarse teeth ventrally, 1 smooth seta dorsally, and several smaller teeth in between. Palp 1-segmented, cylindrical, about 3 times as long as wide, unornamented, and armed apically with 2 smooth and subequal setae.

Maxillula (Figure 43) with relatively small praecoxa, arthrite of which rectangular, long, unornamented, and armed with 1 strong anterior surface setae, and 4 apical elements (probably 3 spines and 1 strong seta). Coxal endite armed with 1 smooth armature element apically, which about 1.5 times as long as endite. Basis longer than coxal endite, armed with 3 naked setae apically. Endopod and exopod completely reduced.

Maxilla (Figure 40) with 2 endites on syncoxa; proximal one armed apically with only 1 bipinnate seta; distal endite twice as long as proximal one, armed apically with 2 naked and 1 unipinnate setae. Basis fused basally with syncoxa, drawn out into strong claw, without seta at base. Endopod represented by minute but distinct segment, armed with 2 bare subequal apical setae.

Maxilliped (Figure 45) with unornamented short syncoxa; basis about 3 times as long as wide, unornamented and unarmed; endopod represented by short curved claw, which ornamented with row of spinules along concave side distally, about 0.7 times as long as basis.

First swimming leg (Figure 46) with smooth coxa and intercoxal sclerite. Basis ornamented with few large spinules around insertation of outer spine. Exopod 3-segmented, armed with 1 outer spine on first segment and 4 armature elements on third segment (2 outer spines and 2 apical geniculate setae); ornamented with few large spinules along outer margin on all segments. Endopod 2segmented, somewhat longer than exopod; first segment reaching slightly beyond distal margin of second exopodal segment, about 3.4 times as long as wide, unarmed, ornamented with few large spinules along outer margin and 1 long row of large spinules along inner margin; second segment armed apically with long geniculate seta and much shorter spine.

Second swimming leg (Figure 47) with smooth coxa and intercoxal sclerite; basis unarmed, ornamented with row of large spinules on outer margin . Exopod 3-segmented, ornamented with large spinules along outer margin, and with hyaline frills on each segment distally on inner side; first segment armed with single outer spine; second segment unarmed; third segment armed with 3 long armature elements (probably outer spine and 2 apical setae), innermost one about 1.3 times as long as exopod. Endopod 1-segmented, linguiform, reaching to middle of first exopodal segment, ornamented with several spinules along apical margin, armed apically with 1 smooth seta, which about 1.5 times as long as segment.

Third swimming leg (Figure 48) with smooth praecoxa, coxa and intercoxal sclerite. Basis robust, armed with long outer seta and ornamented with 

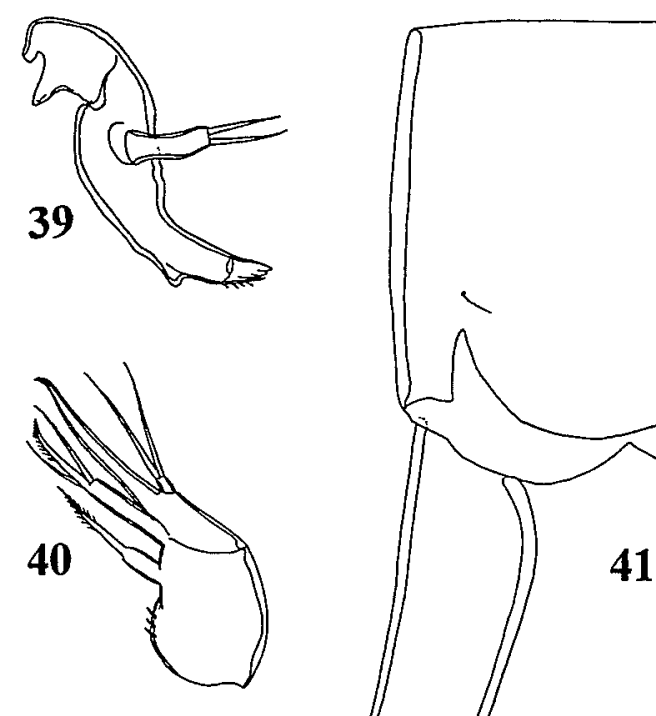


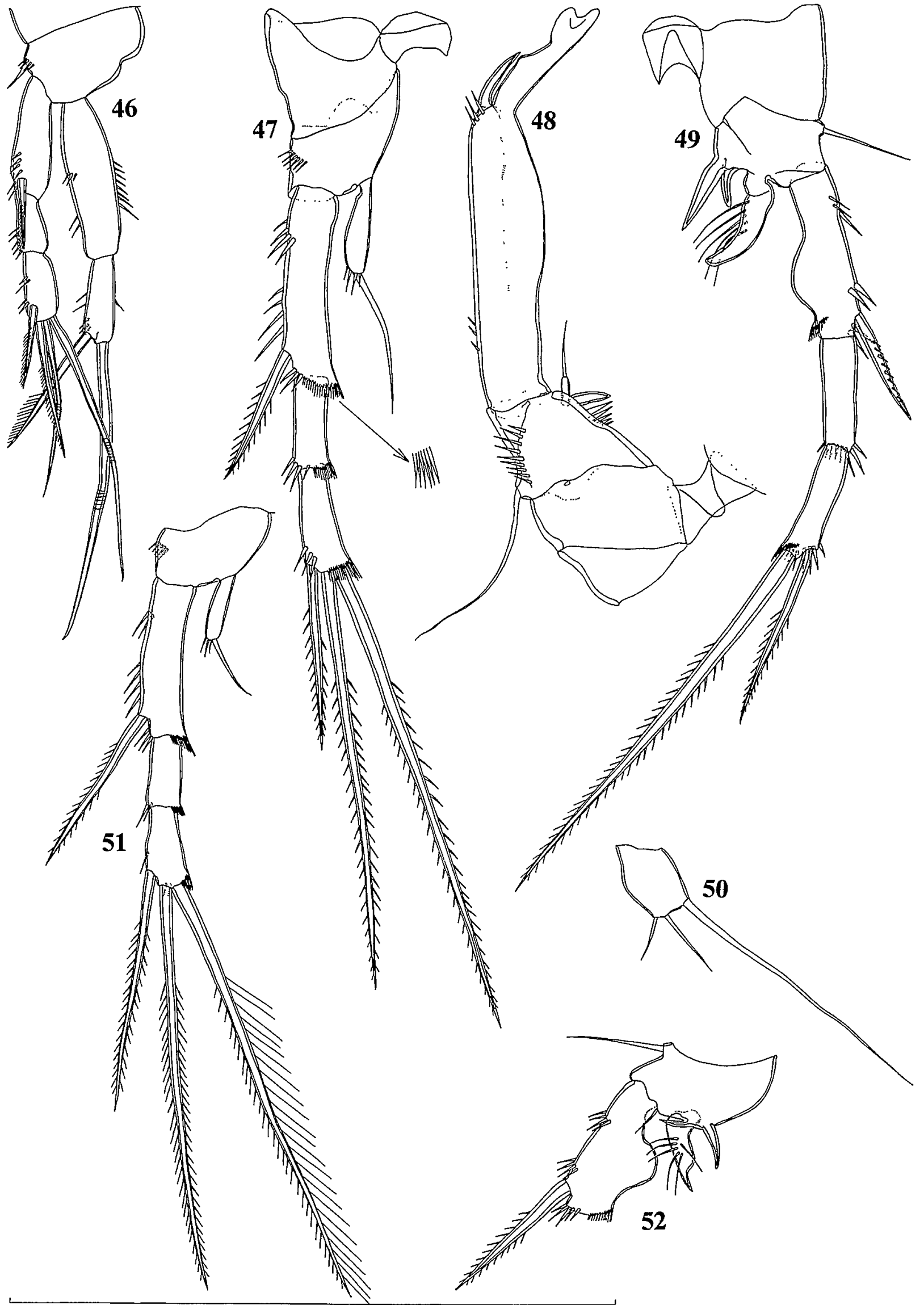

Figures 46-52 Parastenocaris kimberleyensis sp. nov., 46-50, holotype (male); 51 and 52, topotype (male): 46, first swimming leg; 47, second swimming leg; 48 , third swimming leg; 49, fourth swimming leg; 50 , fifth leg; 51, second swimming leg; 52, basis, endopod and first exopodal segment of fourth swimming leg. Scale $=0.1 \mathrm{~mm}$. 
longitudinal row of very large spinules along distal part of inner margin (distalmost strongest) and diagonal row of spinules close to outer margin. Endopod minute, 1-segmented, smaller than largest spinule on inner margin, unornamented and armed apically with smooth seta, which twice as long as segment. Exopod with both segments fused; ancestral proximal segment about 4 times as long as wide, somewhat swollen at distal part of inner margin, armed subapically with strong, short, smooth and curved spine, which reaching middle of apophysis; ancestral distal segment (apophysis) much smaller, oriented inward, unarmed and unornamented, terminating in U-shaped thin chitinous structure.

Fourth swimming leg (Figure 49) with smooth coxa, intercoxal sclerite and basis; basis armed with slender and smooth outer seta, inner-distal corner of basis produced into 2 large, heavily sclerotized claws, longer one almost as long as endopod. Exopod 3-segmented, ornamented with few large spinules along outer margin, and first and third segment with hyaline frills distally on inner side; first segment with swollen distal part of inner margin, armed with single outer spine; second segment unarmed; third segment armed with outer spine and very long and strong apical seta. Endopod 1-segmented, about 0.6 times as long as first exopodal segment, claw-like, curved inwards, unarmed and ornamented with longitudinal row of very long and slender spinules. Endopod and basal claws resembling powerful pincers.

Fifth leg (Figure 50) simple semitrapezoidal cuticular plate, unornamented and armed with 3 smooth setae along distal margin; outermost seta (ancestral basal one) longest, about 4 times longer than median one (which slightly shorter than plate) and about 6.5 times as long as innermost seta. Fifth legs distinct at base (Figure 35) with space between them of about 2 legs width.

Sixth legs (Figure 35) completely fused, forming single large operculum covering gonopore, which represents $80 \%$ of genital somite width, ornamented with transverse row of spinules along posterior margin and unarmed.

\section{Female (allotype)}

Body length, excluding caudal setae, $473 \mu \mathrm{m}$. Habitus, ornamentation of prosomal somites, colour and nauplius eye similar to male. Genital doublesomite (Figures 63) about as long as wide (ventral view), without any trace of subdivision, ornamented only with 6 posterior sensilla ( 2 dorsal, 2 ventral and 2 lateral). Genital complex (Figure 58) occupying anterior ventral half of genital doublesomite; genital apertures paired, each closed off by small, unarmed operculum derived from vestigial sixth leg; median copulatory pore located anteriorly between genital apertures; seminal receptacles trapezoidal, small; copulatory duct not clearly visible inside somite. Caudal ramus (Figure 62), antenna (Figure 61), mandibula, maxillula, maxilla, maxilliped, first swimming leg (Figure 53) and second swimming leg (Figure 55) similar to male.

Antennula (Figure 56) 7-segmented, unornamented, approximately as long as cephalothorax, with broad aesthetasc on fourth segment, reaching middle of seventh segment, and more slender apical aesthetasc on seventh segment, which fused basally to apical seta; setal formula as follows: $0.5 \cdot 5 \cdot 2.1 .0 .9$. Proximalmost seta on second segment and 1 seta on seventh segment articulating on basal part; all setae smooth and without breaking plane. Length ratio of antennular segments, from proximal end, $1: 2.6: 1.5: 1.6: 0.8$ : $0.9: 1.5$.

Third swimming leg (Figure 54) with smooth intercoxal sclerite; coxa and basis ornamented with row of spinules near outer margin; basis armed with long and smooth outer seta, which about 0.7 times as long as exopod. Exopod 2-segmented, ornamented with large spinules along outer margin, both segments with hyaline frills distally on inner side; first segment armed with single outer spine; second segment armed with outer spine and apical strong seta. Endopod 1-segmented, with ancestral apical spine completely fused to segment, but still bipinnate; reaching $2 / 3$ of first exopodal segment.

Fourth swimming leg (Figures 57 and 59) with first exopodal segment with inner margin straight and without spiniform processes on basis. Endopod 1-segmented, with ancestral apical spine fused to segment, with 3 large spinules at its base and unipinnate along inner margin. Other details similar to male.

Fifth leg (Figures 60 and 63) bilobate simple cuticular plate, ornamented with cuticular pore at base of outer (basal) lobe and with ring of spinules around acute extension of inner (endopodal) lobe. Basal lobe armed with long basal seta and small spine (or maybe spinule); inner lobe armed with two smooth and much shorter setae on outer margin (probably ancestral exopodal armature). Fifth legs separated medially, space between them less than one leg width.

Sixth leg (Figure 58) small cuticular plate, covering gonopore, unornamented and unarmed.

\section{Variability}

Body lengths of males range from $408 \mu \mathrm{m}$ to 500 $\mu \mathrm{m}$ (467 $\mu \mathrm{m}$ average; $\mathrm{n}=4)$; only one female was collected and studied. Topotype male with comparatively longer spines on second swimming leg (Figure 51) and with smaller basal processes on fourth swimming leg (Figure 52), although they are drown in slightly different positions than those in the holotype. No other form of variability was observed. 


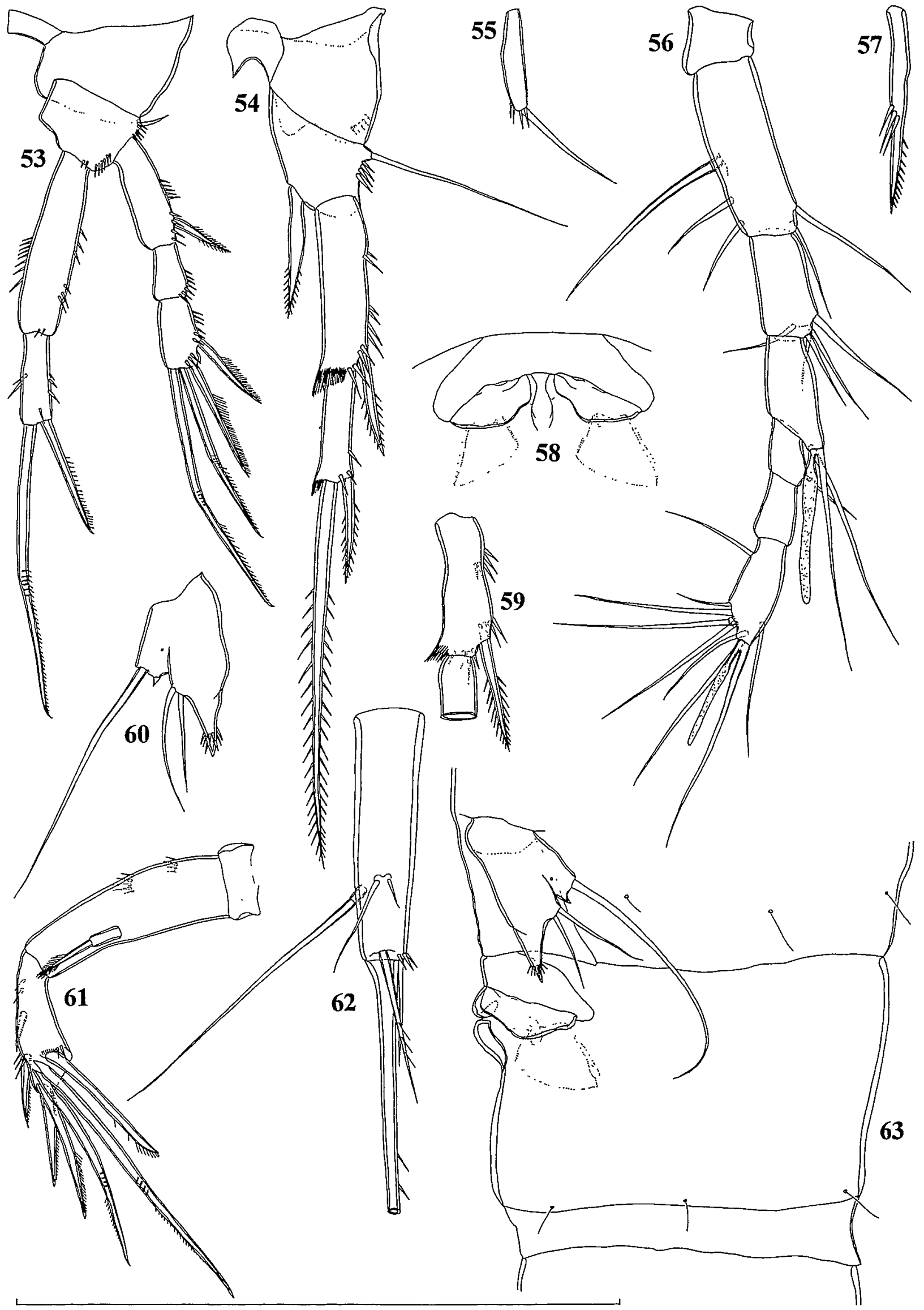

Figures 53-63 Parastenocaris kimberleyensis sp. nov., allotype (female): 53, first swimming leg; 54, third swimming leg; 55 , endopod of second swimming leg; 56, antennula; 57, endopod of fourth swimming leg; 58, genital area, ventral view; 59, first exopodal segment of fourth swimming leg; 60, fifth leg; 61, antenna; 62, right caudal ramus, lateral view; 63, fifth pedigerous and genital double-somite, lateral view. Scale $=0.1 \mathrm{~mm}$. 


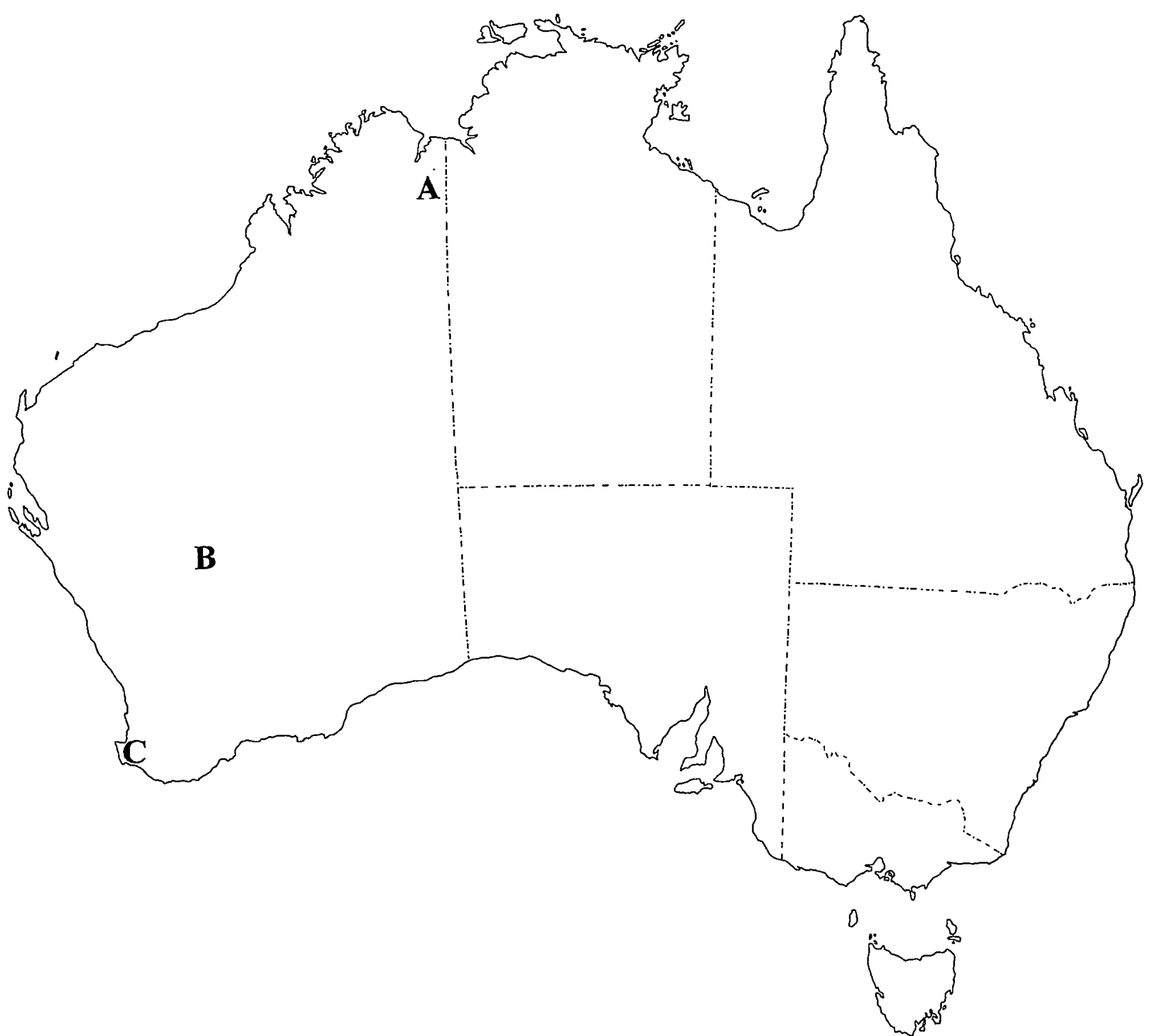

Figure 64 Distribution of the Australian Parastenocarididae: A, Parastenocaris kimberleyensis sp. nov.; B, Parastenocaris solitaria Karanovic, 2004; C, Parastenocaris eberhardi sp. nov.

\section{Etymology}

The species is named after the Kimberley Region, where it was collected.

\section{Distribution}

Parastenocaris kimberleyensis sp. nov. is so far known from a single monitoring bore in the Kimberley district, northeastern Western Australia (Figure 64).

\section{DISCUSSION}

Of the 224 or so described species and subspecies (together with the two new species described above) of the genus Parastenocaris, $18(8 \%)$ are still known only from females, including the first Australian representative $P$. solitaria Karanovic, 2004. This, in conjunction with the high level of convergence in subterranean interstitial habitats, makes phylogenetic analyses of this genus very difficult. Furthermore, some recent publications have added unnecessary confusion in this field. For instance Martinez Arbizu (1997) assigned his new species $P$. hispanica to the "fontinalis"-group. Moreover he analyzed the "phylogenetic relationships within the fontinalis-group", but considered only five species and subspecies, despite the fact that the "fontinalis"-group contains more than 60 taxa. However, based on the Lang's (1948) classification, $P$. hispanica is an obvious member of the "proserpina"-group. Large harpacticoid genera usually accumulate numerous synonyms during the course of their taxonomic history, and the genus Parastenocaris is certainly no exception; for example Reid (1995) established at least three new synonyms of $P$. brevipes Kessler, 1913. Sexual dimorphism and even polymorphism in caudal rami shape (Schminke 1991) is another phenomenon of this 
genus which could contribute to further discoveries of new synonyms, but it is clear that the present number of species is only a small fraction of the total number to be expected (Reid 1982; Boxshall and Jaume 2000). Typical Parastenocaris habitats are only fragmentarily investigated on most continents, including Australia (Karanovic 2004). Future genetic investigations of similar morphological forms (considered now as one species) may even double the final number of species. So, even an estimation of 1000 or more species does not sound impossible (although it is only a speculation). However, the number of different phylogenetic lineages in the genus is limited to around a dozen (depending on how we treat some of the South American groups established by Noodt $(1962,1963$, 1972)), indicating a very slow rate of evolution in this genus. Thus the assumption made by Boxshall and Jaume (2000) "that tectonic events have shaped modern distributions more than subsequent dispersal events" sounds so acceptable for Parastenocaris. Even the two Australian species described in this paper are not some bizarre creatures, but fit well into two existing groups of species originally defined by Lang (1948).

Parastenocaris eberhardi belongs to the "minuta"group of species, the fourth leg basis having five large spinules around the base of the endopod in male. Although this group was originally defined by Lang (1948) to have "Einwärts von Enp.P4 Männchen sitzen 2-4 Borsten", this diagnosis was slightly emended by Karanovic and Bobic (1998) to include those species with only one inner basal spinule around the endopod. Also some species with more than four basal spinules have been described and assigned to the "minuta"-group: $P$. arenicola Chappuis, 1954 from Madagascar; $P$. cornuta Chappuis, 1955 from Lake Tanganyika; $P$. forficulata Chappuis, 1952 from Madagascar; $P$. lusitanica Noodt and Galhano, 1969 from Portugal; $P$. madagascarensis Chappuis, 1952 from Madagascar; P. marlieri Chappuis, 1955 from Lake Tanganyika; $P$. oligoalina Cottarelli, Bruno and Venanzetti, 1995 from Sardinia; and even in some populations of $P$. vicesima Klie, 1935 from Helgoland (Kiefer, 1960), which Lang (1948) had previously included in the "minuta"-group. Galassi and De Laurentiis (2004) were probably unaware of this fact, since they did not include Parastenocaris serbica Karanovic and Bobic, 1998 into their list of the "minuta"-group, nor the abovementioned $P$. arenicola, $P$. forficulata, $P$. lusitanica, $P$. madagascarensis and $P$. marlieri, although they included $P$. cornuta and $P$. oligoalina. However, I do agree with their conclusion that "the evidence already available strongly suggest polyphyletic origin of the minuta-group", a constatation nicely demonstrated by separating a new genus Simplicaris.
Parastenocaris eberhardi has the same combination of a "double" integumental window on the cephalothorax and paired lateral windows on the third and fourth (preanal) urosomites in female as Parastenocaris solitaria Karanovic, 2004, a species described also from Western Australia, but almost $800 \mathrm{~km}$ NNE from the former species (Figure 64). Because of the occurrence of integumental windows in distantly related taxa, as well as of similar structures in several other crustacean groups other than copepods, Lang (1948) stated that they have no phylogenetic significance. However, within the Harpacticoida at the alpha-taxonomic level their form and location on the body are constant within species, and have been useful in species discrimination in the Canthocamptidae (Hamond 1987; Por and Hadel 1986; Hosfeld 1999). Although it is reasonable to assume that $P$. solitaria also belongs to the "minuta"-group, its position cannot be verified woithout males. Females of $P$. eberhardi can be distinguished from those of $P$. solitaria by the following 13 characters: cuticular pits present; sensilla much longer; short rows of ventrolateral spinules on the third urosomite absent; anal somite longer; caudal rami shorter and less cylindrical; caudal rami armed with three lateral setae instead of two; innermost apical setae on caudal rami much longer; allobasis of antenna shorter; maxillula with three armature elements on coxal endite instead of two; distal endite of maxilla not reduced; endopod of fourth swimming leg ornamented with two spinules; fifth leg with somewhat shorter distal spiniform process; and cuticular window on fifth leg present (see Karanovic 2004). Actually, the cuticular window on the fifth leg in both sexes of $P$. eberhardi is something not previously recorded in the genus Parastenocaris, except perhaps in $P$. pasquinii Cottarelli, 1972 (see Bruno and Cottarelli 1998, figure 11F), but these two species differ remarkably from each other. The new Australian species can be easily distinguished from its congeners also by the characteristic shape of the third leg in male, which is somewhat similar only to that of $P$. madagascarensis from Madagascar and $P$. aethiopica Cottarelli and Bruno, 1995 from Ethiopia (see Chappuis 1952; Cottarelli and Bruno 1995). These two species seem to be most closely related to $P$. eberhardi and $P$. solitaria, and they all have the same pattern of integumental windows on the urosomites. However, they can be easily distinguished from $P$. eberhardi by a number of characters, including caudal rami shape, male fourth leg shape of endopod and third legs endopods not completely reduced. Paired lateral integumental windows on the third and fourth urosomites in females (and/or on the fourth and fifth in males) have also been described for the following three species: $P$. arenosa Fryer, 1956 from sandy beaches of Lake Nyasa; $P$. forficulata 
Chappuis, 1952 from Madagascar; and P. quollensis Cottarelli and Bruno, 1995 from Ethiopia. This character should be considered in all future phylogenetic analyses of Parastenocaris, since it shows a clear Eastern Gondwana connection for the two Australian species, as well as many other Australian copepods with freshwater origins (see Karanovic 2003, 2004). Conversly, the cephalothoracic integumental window has no phylogenetic importance in this family, as noted in general by Lang (1948), since it has been recorded in completely unrelated taxa (Karanovic 2004).

Parastenocaris kimberleyensis belongs to the "brevipes"-group of species (having the characteristic endopodal complex of the male fourth leg; the long distally serrate endopod of the female fourth leg; the tapering caudal ramus with dorsal and lateral setae inserted around midlength; the sixth legs in male fused into a single operculum; and the bilobate fifth leg in female), which was defined by Lang (1948) and named after the type species of the genus. Most recently Galassi and De Laurentiis (2004) proposed "retaining within Parastenocaris only those species belonging to the brevipes-group (as revised by Reid 1995), and to relegate the remainder presently assigned to this genus as Parastenocaris s.l., pending the revision of the family". I prefer to wait for that revision instead of using sensu stricto and sensu lato terms, because they provide no real advancement to our knowledge on this complex taxon. Besides $P$. brevipes, which is the only member of the genus with a Holarctic distribution (see Lang 1948; Reid 1995), 16 species have been described so far in the "brevipes"-group: five of them from Sri Lanka by Enckell (1970) $[P$. brincki, $P$. irenae, $P$. lanceolata, $P$. noodti and $P$. singhalensis]; four from the United States by Pennak (1939), Borutzky (1952), Whitman (1984) and Reid (1991) [P. starretti, P. wilsoni, P. texana and $P$. palmerae respectively]; three from Japan by Miura $(1962,1969)$ and Kikuchi $(1970)[P$. oshimaensis, $P$. biwae and $P$. hinumaensis respectively]; two from India by Ranga Reddy (2001) [P. gayatri and P. savita]; one from China by Shen and Tai (1973) [P. longipoda]; and one from Sumatra by Chappuis (1931) [P. feuerborni]. Parastenocaris biwae, $P$. starretti and $P$. wilsoni were consequently synonymized with $P$. brevipes by Reid (1995), who also recognized "the possible origin of the brevipes- group in tropical Asia". Parastenocaris texana, because of the incomplete original description, should be placed as incertae sedis until a proper redescription of the type material is presented. Reid (1995) expressed doubts about the position of her P. palmerae in the "brevipes"-group, but there are currently no strong reasons to exclude this species. Galassi and De Laurentiis (2004) also included P. longicaudis Chappuis, 1931 and P. arctica Bortutzky, 1952 in this group, although they are known only as females and their statuses could not be verified (see Lang 1948; Borutzky 1952). Together with $P$. kimberleyensis 14 valid species could be recognized today in the "brevipes"-group, and a key to aid in their difficult determination is given below (based solely on the morphology of males, since females of $P$. brincki, $P$. lanceolata and $P$. singhalensis are still unknown).

Key to the "brevipes"-group of Parastenocaris

1. Third leg in adult male without endopod....... 9

- Same appendage with endopod ......................... 2

2. Third leg endopod reduced to single slender seta.

- Third leg endopod small but distinct segment.

3. Fourth leg endopod with transverse subapical row of 3 long spinules. P. feuerborni Chappuis, 1931

- Same segment with longitudinal row of 5-6 long setules P. kimberleyensis sp. nov.

4. Fifth leg with inner-distal corner produced posteriorly as spiniform process . 5

- Same appendage lacking spiniform process .. 6

5. Fifth leg with only 2 setae

P. brincki Enckell, 1970

- Same leg armed with 4 setae

P. palmerae Reid, 1991

6. Fourth leg endopod 2-segmented, with 2 apical spinules.

- Same ramus 1-segmented, with more than 2 spinules 8

7. Third leg first exopodal segment without subapical spine

P. longipoda Shen and Tai, 1973

- Same segment with well developed outer spine apically P. savita Ranga Reddy, 2001

8. Third leg first exopodal segment armed with large dentate process on inner margin ...

P. gayatri Ranga Reddy, 2001

- Same segment with smooth inner margin ........ P. brevipes Kessler, 1913

9. Anal operculum smooth 11

- Anal operculum with row of spinules ............ 10

10. Male fourth leg endopod conical and smooth.. P. oshimaensis Miura, 1962

- Same ramus sickle-shaped, with 1 long spinule P. hinumaensis Kikuchi, 1970

11. Fifth leg inner-distal corner produced posteriorly as spiniform process P. irenae Enckell, 1970 
- Same appendage lacking spiniform process 12

12. Anal somite with 2 dorsal rows of spinules...... P. noodti Enckell, 1970

- Anal somite without ornamentation 13

13. Fourth leg endopod with 4 long spinules .......... P. singhalensis Enckell, 1970

- Same ramus smooth, conical, sharply pointed. P. lanceolata Enckell, 1970

In his revision of the family Parastenocarididae, Jakobi (1972) divided this group of species into five separate genera (all, except the first one, described as new): Parastenocaris, Oshimaensicaris, Biwaecaris, Enckellcaris and Brinckicaris. The superficial nature of this revision is highlighted by the fact that the type species of his genus Biwaecaris is synonymous with the type species of Parastenocaris (see Reid 1995). Although it is generally accepted that some of the species groups within Parastenocaris will be elevated to the generic level (Enckell 1970; Schminke 1976; Por and Hadel 1986; Reid 1994; Cottarelli et al. 1995; Martinez Arbizu 1997; Galassi and De Laurentiis 2004) it is currently untenable to base such a revision solely on morphology. Numerous convergences are normally expected in genera that have invaded freshwater habitats during or before the Pangaean era and partly (or completely?) already stygomorphic (from the marine psammon). However, the "brevipes"group is one of the best defined and most compact groups and, since it contains the type species the generic name of Parastenocaris will probably persist for a long time. Galassi and De Laurentiis (2004) even defined the members of this group as Parastenocaris s.s. and provided an overview of all major important morphological characters. Their ecological niche is generally very close to the surface ( $P$. brevipes in Europe even inhabits Sphagnum bogs), which enables them to grow bigger than other members of the genus, reaching usually 0.5 or $0.6 \mathrm{~mm}$. The main reason for this is probably the bigger sand particle size near the surface (a consequence of natural process of sedimentation), but a more abundant food imput may be responsible as well. The presence of this group in northern part of Australia may suggest their relatively recent arrival, if the hypothesis of the origin of this group in tropical Asia is correct (Reid 1995). But, in order to arrive at more reliable zoogeographic conclusions a lot more work is required on the taxonomy, ecology and ethology of this group.

\section{ACKNOWLEDGEMENTS}

Thanks are extended to the Western Australian Museum for kindly granting me the status of
Research Associate, which enabled me to use most of the facilities of the Museum and privileges of staff. I am also grateful to Mr Stefan Eberhard, "Cave Works" Western Australia, who financially supported part of this work from various projects and grants. The Argyle Diamond Mine, Western Australia, supported part of this work financially. Dr William F. Humphreys (Western Australian Museum) kindely provided the material of Parastenocaris kimberleyensis. For his valuable comments on an early draft of this paper, I am very grateful to Dr Mark S. Harvey (Western Australian Museum). This manuscript benefited greatly from constructive criticism by two reviewers (Dr Giuseppe L. Pesce and Dr Diana M.P. Galassi, both from the University of L'Aquila, Italy), although the responsability for any rough criticism left in the paper is completely mine.

\section{REFERENCES}

Aubrecht, R. and Kozur, H. (1995). Pokornyopsis (Ostracoda) from submarine fissure fillings and cavities in the Late Jurassic of Czorsztyn Unit and the possible origin of the recent anchialine faunas. Neues Jahrbuch fur Geologie Paleontologie 196: 1-17.

Baltanas, A. and Danielopol, D. (1995). Cladistic analysis of Danielopolina species (Ostracoda: Thaumatocyprididae) and the origin of anchialine fauna. Mitteilungen aus dem Hamburgischen Zoologischen Museum und Institut 92: 315-324.

Barr, T.C. (1973). Refugees from the Ice Age. Natural History (May 1973): 26-35.

Bartsch, I. (1993). Ctenocheilocaris enochra, a new mystacocarid (Crustacea) from Western Australia. In F.E. Wells, D.I. Walker, H. Kirkman and R. Lethbridge (eds). The Marine Flora and Fauna of Rottnest Island, Western Australia 1, pp. 105-111, Western Australian Museum, Perth.

Borutzky, E.V. (1952). Harpacticoida presnykh vod. Fauna SSSR, Rakoobraznye 3 (4). USSR Academy of Sciences, Moscow-St Petersburg.

Boxshall, G.A. and Jaume, D. (2000). Making waves: the repeated colonization of freshwater by copepod crustaceans. Advances in Ecological Research 31: 61-79.

Bradbury, J.H. (2000). Western Australian stygobiont amphipods (Crustacea: Paramelitidae) from the Mt Newman and Millstream regions. Records of the Western Australian Museum, Supplement 60: 1-102.

Bradbury, J.H. (2002). Melitid amphipods of Barrow Island, Western Australia, Part II, Recent discoveries. Records of the Western Australian Museum 21: 83-103.

Bradbury, J.H. and Williams, W.D. (1996a). Freshwater amphipods from Barrow Island, Western Australia. Records of the Australian Museum 48: 33-74.

Bradbury, J.H. and Williams, W.D. (1996b). Two new species of anchialine amphipod (Crustacea: Hadziidae: Liagoceradocus) from Western Australia. Records of the Western Australian Museum 17: 395-409.

Bradbury, J.H. and Williams, W.D. (1997a). Amphipod (Crustacea) diversity in underground waters in 
Australia: an Aladdin's Cave. Memoirs of Museum Victoria 56: 513-519.

Bradbury, J.H. and Williams, W.D. (1997b). The amphipod (Crustacea) stygofauna of Australia: description of new taxa (Melitidae, Neoniphargidae, Paramelitidae), and a synopsis of known species. Records of the Australian Museum 49: 249-341.

Bruce, N.L. and Humphreys, W.F. (1993). Haptolana pholeta sp. nov., the first subterranean flabelliferan isopod crustacean (Cirolanidae) from Australia. Invertebrate Taxonomy 7: 875-884.

Bruno, M.C. and Cottarelli, V. (1998). Description of Parastenocaris amalasuntae n.sp. and new data on Parastenocaris proserpina and Parastenocaris pasquinit from subterranean waters of central Italy (Copepoda, Harpacticoida). Italian Journal of Zoology 65: 121-136.

Chappuis, P.A. (1931). Copepoda Harpacticoida der Deutschen Limnologischen Sunda-Expedition. Archiv für Hydrobiologie Supplement 8: 512-584.

Chappuis, P.A. (1933). Copépodes (première série), Avec l'énumération de tous copépodes cavernicoles connus en 1932. Archives de Zoologie Expérimentale et Générale 76: 1-57.

Chappuis, P.A. (1940). Die Harpacticoiden des Grundwassers des unteren Maintales. Archiv für Hydrobiologie 36: 286-305.

Chappuis, P.A. (1952). Copépodes Harpacticoides psammiques de Madagascar. Mémoires de l'Institut Scientifique de Madagascar 7: 145-160.

Chappuis, P.A. (1954). Recherches sur la faune interstitielle des sédiments marins et d'eau douce a Madagascar, IV. Copépodes Harpacticoides psammiques de Madagascar. Mémoires de l'Institut Scientifique de Madagascar (A) 9: 45-73.

Chappuis, P.A. (1955). Harpacticoides psammiques du Lac Tanganika. Revue de Zoologie et de Botanique Africaines 51: 68-80.

Cottarelli, V. and Bruno M.C. (1995). First record of Parastenocarididae (Crustacea, Copepoda, Harpacticoida) from subterranean waters of Ethiopia and the description of three new species. Journal of African Zoology 109: 467-479.

Cottarelli, V., Bruno M.C. and Venanzetti F. (1995). Two new species of Parastenocaris from the interstitial waters of rivermouths in Latium and Sardinia. Fragmenta Entomologica Roma 26: 229-247.

De Laurentiis, P., Pesce, G.L. and Humphreys, W.F. (1999). Copepods from ground waters of Western Australia, IV. Cyclopoids from basin and craton aquifers (Crustacea: Copepoda: Cyclopidae). Records of the Western Australian Museum 19: 243-257.

De Laurentiis, P., Pesce, G.L. and Humphreys, W.F. (2001). Copepods from ground waters of Western Australia, VI. Cyclopidae (Crustacea: Copepoda) from the Yilgarn Region and the Swan Coastal Plain. Records of the Western Australian Museum, Supplement 64: 115-131.

Dussart, B. and Defaye, D. (1990). Répertoire mondial des crustacés copépodes des eaux intérieures, III. Harpacticoïdes. Crustaceana, Supplement 16: 1-384.

Enckell, P.H. (1970). Parastenocarididae (Copepoda Harpacticoida) from Ceylon. Arkiv för Zoologi 22: 545556.
Fryer, G. (1956). New species of cyclopoid and harpacticoid copepods from sandy beaches of Lake Nyasa. Annals and Magazine of Natural History 9: 225 249.

Galassi, D.M.P. and De Laurentiis, P. (2004). Towards a revision of the genus Parastenocaris Kessler, 1913: establishment of Simplicaris gen. nov. from groundwaters in central Italy and review of the $P$. brevipes-group (Copepoda, Harpacticoida, Parastenocarididae). Zoological Journal of the Linnean Society 140: 417-436.

Hamilton-Smith, E. (1967). The Arthropoda of Australian caves. Journal of the Australian Entomological Society 6: 103-118.

Hamond, R. (1987). Non-marine harpacticoid copepods of Australia, I. Canthocamptidae of the genus Canthocamptus Westwood s. lat. and Fibulacamptus, gen. nov., and including the description of a related new species of Canthocamptus from New Caledonia. Invertebrate Taxonomy 1: 1023-1247.

Harvey, M.S. (1998). Unusual new water mites (Acari: Hydracarina) from Australia, Part 1. Records of the Western Australian Museum 19: 91-106.

Harvey, M.S., Gray, M.R., Hunt, G.S. and Lee, D.C. (1993). The cavernicolous Arachnida and Myriapoda of Cape Range, Western Australia. Records of the Western Australian Museum, Supplement 45: 129-144.

Holthuis, L.B. (1960). Two new species of atyid shrimps from subterranean waters in N.W. Australia (Decapoda: Natantia). Crustaceana 1: 47-57.

Hosfeld, B. (1999). Ultrastructure of ionocytes from osmoregulatory integumental windows of Tachidius discipes and Bryocamptus pygmaeus (Crustacea, Copepoda, Harpacticoida) with remarks on the homology of nonsensory dorsal organs of crustaceans. Acta Zoologica (Stockholm) 80: 61-74.

Howarth, F.G. (1980). The zoogeography of specialized cave animals: a bioclimatic model. Evolution 34: $394-$ 406.

Humphreys, W.F. (1993a). Stygofauna in semi-arid tropical Western Australia: a Tethyan connection? Mémoires de Biospéologie 20: 111-116.

Humphreys, W.F. (1993b). The significance of the subterranean fauna in biogeographical reconstruction: examples from Cape Range peninsula, Western Australia. Records of the Western Australian Museum, Supplement 45: 165-192.

Humphreys, W.F. (1993c). Cave fauna in semi-arid tropical Western Australia: a diverse relict wet-forest litter fauna. Mémoires de Biospéologie 20: 105-110.

Humphreys, W.F. (2000). Karst wetlands biodiversity and continuity through major climatic change: an example from arid tropical Western Australia. In B. Gopal, W.J. Junk and J.A. Davis (eds). Biodiversity in wetlands: assessment, function and conservation, vol. 1. pp. 227258. Backhuys, Leiden.

Humphreys, W.F. (2001). Groundwater calcrete aquifers in the Australian arid zone: the context to an unfolding plethora of stygal biodiversity. Records of the Western Australian Museum, Supplement 64: 63-83.

Huys, R. and Boxshall, G.A. (1991). Copepod Evolution. The Ray Society, London. 
ICZN (1999). Fourth edition. The International Trust for Zoological Nomenclature, London.

Jakobi, H. (1972). Trends (Enp.P4 ?) innerhalb der Parastenocarididen (Copepoda Harpacticoidea). Crustaceana 22: 127-146.

Jaume, D., Boxshall, G.A. and Humphreys, W.A. (2001). New stygobiont copepods (Calanoida; Misophrioida) from Bundera Sinkhole, an anchialine cenote in northwestern Australia. Zoological Journal of the Linnean Society 133: 1-24.

Jaume, D. and Humphreys, W.F. (2001). A new genus of epacteriscid calanoid copepod from an anchialine sinkhole on northwestern Australia. Journal of Crustacean Biology 21: 157-169.

Karanovic, I. and Marmonier, P. (2002). On the genus Candonopsis (Crustacea: Ostracoda: Candoninae) in Australia, with a key to the world recent species. Annales de Limnologie 38: 199-240.

Karanovic, I. and Marmonier, P. (2003). Three new genera and nine new species of the subfamily Candoninae (Crustacea, Ostracoda, Podocopida) from the Pilbara Region (Western Australia). Beaufortia 53: 1-51.

Karanovic, T. (2003). First representative of the genus Allocyclops Kiefer, 1932 (Crustacea, Copepoda, Cyclopoida) from the Australian subterranean waters. Annales de Limnologie 39: 141-149.

Karanovic, T. (2004). Subterranean Copepoda from arid Western Australia. Crustaceana Monographs 3: 1-366.

Karanovic, T. and Bobic, M. (1998). Two new species of Copepoda Harpacticoida from east Serbia (Balkan Peninsula): Parastenocaris serbica sp. n. and Bryocamptus (R.) borus sp.n. Crustaceana 71: 171-184.

Karanovic, T. and Pesce, G.L. (2002). Copepods from ground waters of Western Australia, VII. Nitokra humphreysi sp. nov. (Crustacea: Copepoda: Harpacticoida). Hydrobiologia 470: 5-12.

Karanovic, T., Pesce, G.L. and Humphreys, W.F. (2001). Copepods from ground waters of Western Australia, V. Phyllopodopsyllus wellsi sp. nov. (Crustacea: Copepoda: Harpacticoida) with a key to world species. Records of the Western Australian Museum 20: 333-344.

Kiefer, F. (1960). Psammobionte Ruderfußkrebse (Crust. Cop.) aus dem Gebiet der Unterweser und von der Insel Helgoland. Zoologischer Anzeiger 165: 30-37.

Kikuchi, Y. (1970). A new species of Parastenocaris (Harpacticoida) from a sandy beach of the Lake Hinuma. Annotationes Zoologicae Japonenses 43: 170173.

Knott, B. and Halse, S.A. (1999). Pilbarophreatoicus platyarthricus n.gen., n.sp. (Isopoda: Phreatoicidea: Amphisopidae) from the Pilbara region of Western Australia. Records of the Australian Museum 51: 33-42.

Kunz, H. (1938). Harpacticoiden vom Sandstrand der Kurischen Nehrung. Kieler Meeresforschungen 3: 148-157.

Lang, K. (1948). Monographie der Harpacticiden. Nordiska Bokhandeln A-B, Lund.

Lee, W. and Huys, R. (2002). A new genus of groundwater Ameiridae (Copepoda, Harpacticoida) from boreholes in Western Australia and the artificial status of Stygonitocrella Petkovski, 1976. Bulletin of the Natural History Museum, London (Zoology) 68: 39-50.
Marmonier, P., Vervier, P., Gibert, J. and Dole-Olivier, M.-J. (1993). Biodiversity in ground waters. Trends in Ecology and Evolution 8: 392-395.

Martínez Arbizu, P. (1997). Parastenocaris hispanica n.sp. (Copepoda: Harpacticoida: Parastenocarididae) from hyporheic groundwaters in Spain and its phylogenetic position within the fontinalis-group of species. Contributions to Zoology 66: 215-226.

Miura, Y. (1962). Subterranean harpacticoid copepods of the Amami Group of the Ryukyu Islands. Annotationes Zoologicae Japonenses 35: 95-105.

Miura, Y. (1969). A new harpacticoid copepod from a sandy beach of Lake Biwa. Annotationes Zoologicae Japonenses 42: 40-44.

Moore, B.P. (1964). Present-day cave beetle fauna of Australia: a pointer to past climatic change. Helictite 3: 3-9.

Moore, B.P., Humphreys, W.F., Decu, V. and Juberthie, C. (2001). Australie. In C. Juberthie and V. Decu (eds.). Encyclopaedia Biospeologica, 3, pp. 2055-2078. Laboratoire souterrain du CNRS, Moulis.

Noodt, W. (1962). Limnisch-subterrane Copepoden der Gattung Parastenocaris Kessler aus Mittelamerika. In E. Titschack and H.-W. Koepcke (eds). Beiträge zur neotropischen Fauna 2. pp. 223-248. VEB Gustav Fischer Verlag, Jena.

Noodt, W. (1963). Subterrane Crustaceen der zentralen Neotropis. Zoologischer Anzeiger 171: 114-147.

Noodt, W. (1972). Drei neue Parastenocaris aus Kolumbien (Crustacea Copepoda), 1. Mitteilung über kolumbianische Grundwasser-Crustaceen. Studies on Neotropical Fauna 7: 101-112.

Noodt, W. and Galhano, M.H. (1969). Studien an Crustacea Subterranea (Isopoda, Syncarida, Copepoda) aus dem Norden Portugals. Publicações do Instituto de Zoologia "Dr. Augusto Nobre" Faculdade de Ciências do Porto 107: 1-75.

Pennak, R.W. (1939). A new copepod from the sandy beaches of a Wisconsin lake. Transactions of the American Microscopic Society 58: 224-227.

Pesce, G.L. and De Laurentiis, P. (1996). Copepods from ground waters of Western Australia, III. Diacyclops humphreysi n.sp. and comments on the Diacyclops crassicaudis complex (Copepoda, Cyclopidae). Crustaceana 69: 524-531.

Pesce, G.L., De Laurentiis, P. and Humphreys, W.F. (1996a). Copepods from ground waters of Western Australia, I. The genera Metacyclops, Mesocyclops, Microcyclops and Apocyclops (Crustacea: Copepoda: Cyclopidae). Records of the Western Australian Museum 18: $67-76$.

Pesce, G.L., De Laurentiis, P. and Humphreys, W.F. (1996b). Copepods from ground waters of Western Australia, II. The genus Halicyclops (Crustacea: Copepoda: Cyclopidae). Records of the Western Australian Museum 18: 77-85.

Poore, G.C.B. and Humphreys, W.F. (1992). First record of Thermosbaenacea (Crustacea) from the Southern Hemisphere: a new species from a cave in tropical Western Australia. Invertebrate Taxonomy 6: 719-725.

Poore, G.C.B. and Humphreys, W.F. (1998). The first record of the Spelaeogriphacea (Crustaceana) from 
Australasia: a new genus and species from an aquifer in the arid Pilbara of Western Australia. Crustaceana 71: 721-742.

Por, F.D. and Hadel, V.F. (1986). Two new species of Attheyella (Copepoda: Harpacticoida: Canthocamptidae) from bromeliads of the Serra da Juréia (São Paulo, Brazil). Journal of Crustacean Biology 6: 777788.

Ranga Reddy, Y. (2001). Discovery of Parastenocarididae (Copepoda, Harpacticoida) in India, with the description of three new species of Parastenocaris Kessler, 1913, from the River Krishna at Vijayawada. Crustaceana 74: 705-733.

Reid, J.W. (1982). Forficatocaris schadeni, a new copepod (Harpacticoida) from central Brazil, with keys to the species of the genus. Journal of Crustacean Biology 2: 578-587.

Reid, J.W. (1991). Diacyclops albus n.sp. and Parastenocaris palmerae n.sp. (Crustacea: Copepoda) from the meiofauna of a stream bed in Virginia, U.S.A. Canadian Journal of Zoology 69: 2893-2902.

Reid, J.W. (1994). Murunducaris juneae, new genus, new species (Copepoda: Harpacticoida: Parastenocarididae) from wet campo in central Brazil. Journal of Crustacean Biology 14: 771-781.

Reid, J.W. (1995). Redescription of Parastenocaris brevipes Kessler and description of a new species of Parastenocaris (Copepoda: Harpacticoida: Parastenocarididae) from the U.S.A. Canadian Journal of Zoology 73: 173-187.

Schminke, H.K. (1976). Systematische Untersuchungen an Grundwasserkrebsen eine Bestandsaufnahme (mit der Beschreibung zweier neuer Gattungen der Familie Parabathynellidae, Bathynellacea). International Journal of Speleology 8: 195-216.

Schminke, H.K. (1981). Perspectives in the study of the zoogeography of interstitial Crustacea: Bathynellacea (Syncarida) and Parastenocarididae (Copepoda). International Journal of Speleology 11: 83-89.

Schminke, H.K. (1991). Sexual dimorphism in caudal rami of Parastenocarididae (Copepoda: Harpacticoida). Proceedings of the Fourth International Conference on Copepoda; Bulletin of the Plankton Society of Japan, Special Volume: 573-584.

Shen, C.-J. and Tai, A.-Y. (1973). Preliminary analysis of the characteristics of the harpacticoid Copepoda fauna of China and description of some new species. Acta Zoologica Sinica 19: 365-384.
Stock, J.H. and Von Vaupel Klein, J.C. (1996). Mounting media revisited: the suitability of Reyne's fluid for small crustacecans. Crustaceana 69: 794-798.

Thurgate, M.E., Gough, J.S., Clarke, A.K., Serov, P. and Spate, A. (2001a). Stygofauna diversity and distribution in Eastern Australian cave and karst areas. Records of the Western Australian Museum, Supplement 64: 49-62.

Thurgate, M.E., Gough, J.S., Spate, A. and Eberhard, S. (2001b). Subterranean biodiversity in New South Wales: from rags to riches. Records of the Western Australian Museum, Supplement 64: 37-47.

Watts, C.H.S. and Humphreys, W.F. (2000). Six new species of Nirridessus and Tjirtudessus (Dytiscidae; Coleoptera) from underground waters in Australia. Records of the South Australian Museum 33: 127-144.

Watts, C.H.S. and Humphreys, W.F. (2001). A new genus and six new species of Dytiscidae (Coleoptera) from underground waters in the Yilgarn palaeodrainage system of Western Australia. Records of the South Australian Museum 34: 99-114.

Watts, C.H.S. and Humphreys, W.F. (2004). Twenty-five new Dytiscidae (Coleoptera) of the genera Tjirtudessus Watts and Humphreys, Nirripirti Watts and Humphreys and Bidessodes Regimbart, from underground waters in Australia. Records of the South Australian Museum 36: 135-187.

Wells, J.B.J. (1986). Copepoda: Marine-interstitial Harpacticoida. In L., Botosaneanu. (ed). Stygofauna Mundi, pp. 321-355. E. J. Brill/Dr W. Backhuys, Leiden.

Whitman, R.L. (1984). Parastenocaris texana, new species (Copepoda: Harpacticoida: Parastenocarididae) from an east Texas sandy stream with notes on its ecology. Journal of Crustacean Biology 4: 695-700.

Wilson, G.D.F. and Ponder, W.F. (1992). Extraordinary new subterranean isopods (Peracarida: Crustacea) from the Kimberley region, Western Australia. Records of the Australian Museum 44: 279-298.

Yager, J. and Humphreys, W.F. (1996). Lesionectes exleyi, sp. nov., the first remipede crustacean recorded from Australia and the Indian Ocean, with a key to the world species. Invertebrate Taxonomy 10: 171-187.

Manuscript received 29 September 2004; accepted 8 March 2005 


\section{CONTENTS VOLUME 22}

\section{Part 1}

\section{N. Warburton, C. Wood, C. Lloyd, S. Song and P. Withers}

The 3-dimensional anatomy of the North-Western Marsupial Mole

(Notoryctes caurinus Thomas 1920) using computed tomography,

$X$-ray and magnetic resonance imaging

F.E. Wells and H. Morrison

Description of Volutoconus hargreavesi calcarelliformis suMbsp. nov.

(Mollusca: Volutidae) from northwestern Australia

\section{R.L. Hoffman}

A new genus and species of trigoniuline milliped from Western Australia (Spirobolida: Pachybolidae: Trigoniulinae)

I. Bartsch

Psammophilous halacarids (Halacaridae, Acari)' from Dampier,

Western Australia. Description of species and faunal comparison of the mesopsammal halacarid fauna of western and eastern Australia

\section{Maryanto}

Taxonomic status of the ricefield rat Rattus argentiventer (Robinson and Kloss, 1916) (Rodentia) from Thailand, Malaysia and Indonesia based on morphological variation

G.C.B. Poore and W.F. Humphreys

Second species of Mangkurtu (Spelaeogriphacea) from north-western Australia

S. Gallego Martínez and G.C.B. Poore

A new species of ingolfiellid amphipod (Crustacea: Amphipoda)

from Western Australia 


\section{Part 2}

C.S. Whisson, F.E. Wells and T. Rose

The benthic invertebrate fauna of the Peel-Harvey Estuary of

south-western Australia after completion of the Dawesville Channel

M.A. Cowan and R.A. How

Comparisons of ground vertebrate assemblages in arid Western Australia

in different seasons and decades

\section{P.A. McLaughlin}

A new genus and species of hermit crab (Crustacea: Anomura:

Paguroidea) from northwestern Australia

W. Zeidler and L. Gershwin

A new species of Australomedusa (Cnidaria: Hydrozoa: Anthomedusae)

from a saline lake in south-western Western Australia

J.T. Jennings, A.D. Austin and N.B. Stevens

The aulacid wasp fauna of Western Australia with descriptions

of six new species

E.M. Exley

Revision of the genus Dasyhesma Michener (Apoidea: Colletidae: Euryglossinae)

D.L. Morgan, M.G. Allen, P. Bedford and M. Horstman

Fish fauna of the Fitzroy River in the Kimberley region of Western Australia

- including the Bunuba, Gooniyandi, Ngarinyin, Nyikina and

Walmajarri Aboriginal names

\section{SHORT COMMUNICATION}

\section{K.E.C. Brennan}

A further record of the spider Microctenonyx subitaneus

(Araneae: Linyphiidae: Erigoninae) in Australia

\section{Part 3}

\section{H. Smit}

The water mite genus Koenikea Wolcott from Australia

(Acari: Hydrachnidia: Unionicolidae)

\section{T. Karanovic}

The genus Metacyclops Kiefer in Australia (Crustacea: Copepoda: Cyclopoida), with description of two new species

\section{S. Martin, K.J. McNamara}

First record of a neolampadoid echinoid from the Paleogene of

Western Australia

N.R. Gunawardene, J.D. Majer

Ants of the southern Carnarvon Basin, Western Australia: An investigation into patterns of association

K. Sanpanich, F.E. Wells and Y. Chitramvong

Distribution of the family Littorinidae (Mollusca: Gastropoda) in Thailand 


\section{Part 4}

T. Komai

A distinctive new species of the deep-water shrimp genus Glyphocrangon

A. Milne-Edwards (Crustacea: Decapoda: Caridea: Glyphocrangonidae)

from southern Australia

\section{H.I. Jones}

The gastrointestinal nematodes of Varanus rosenbergi (Reptilia: Varanidae) and the effects of habitat change in southern Australia, with particular reference

to the genus Abbreviata (Physalopteroidea)

\section{V.W. Framenau}

The wolf spider genus Artoria Thorell in Australia: new synonymies and generic transfers (Araneae, Lycosidae)

\section{Bartsch}

Lohmannella and Simognathus (Halacaridae: Acari) from Western Australia: description of two new species and reflections on the distribution of these genera

\section{G.W. Kendrick}

A new species of Bothriembryon (Mollusca: Gastropoda: Bulimulidae) from the Pliocene Roe Calcarenite, Eucla Basin, Western Australia

\section{G.D. Edgecombe}

A troglomorphic species of the centipede Cryptops (Trigonocryptops)

(Chilopoda: Scolopendromorpha) from Western Australia

\section{A.J. Bruce}

New species of Periclimenaeus Borradaile (Crustacea: Decapoda:

Pontoniinae) from Ashmore Reef, North Western Australia, with

remarks on P. pachydentatus Bruce, 1969

H. Morrison and F.E. Wells

A new species of Melo (Gastropoda: Volutidae) from northwestern Australia

\section{T. Karanovic}

Two new subterranean Parastenocarididae (Crustacea, Copepoda,

Harpacticoida) from Western Australia 


\section{INDEX TO AUTHORS}

Allen, M.G.

Austin, A.D.

Bartsch, I.

Bedford, P.

Brennan, K.E.C.

Bruce, A.J.

325

Chitramvong, $Y$.

Cowan, M.A.

Edgecombe, G.D.

Exley, E.M.

Framenau, V.W.

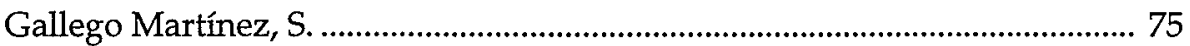

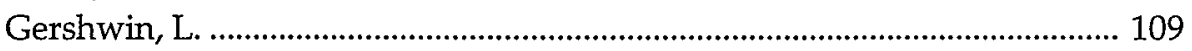

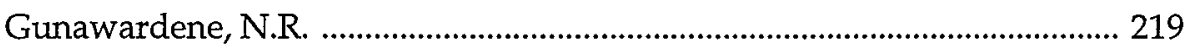

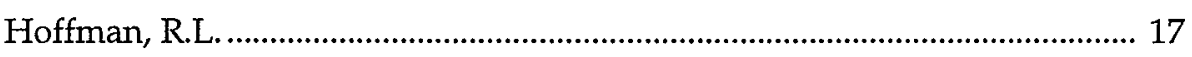

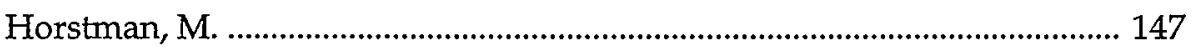

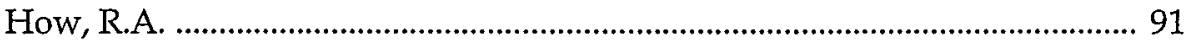

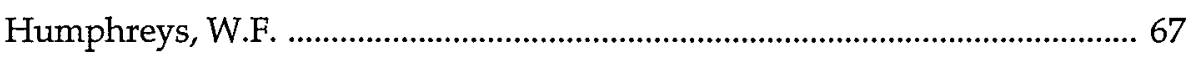

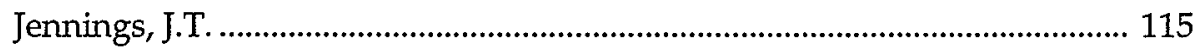

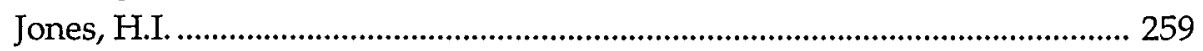

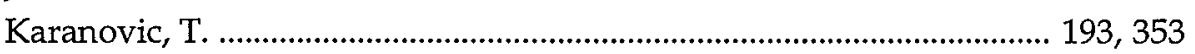

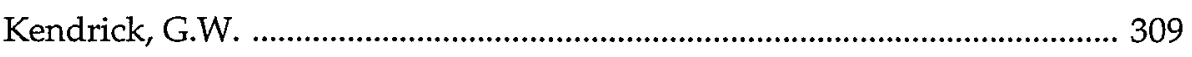

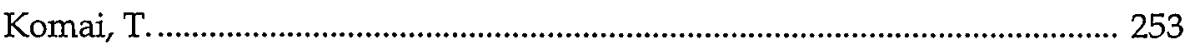

Lloyd, C. .

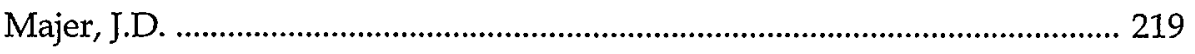

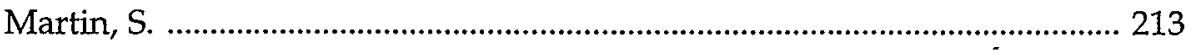

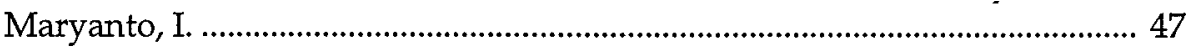

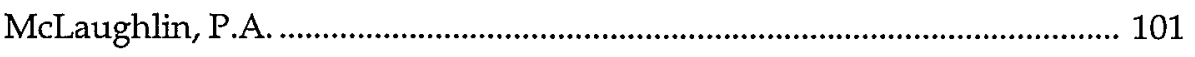

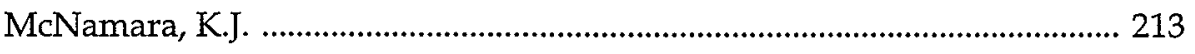

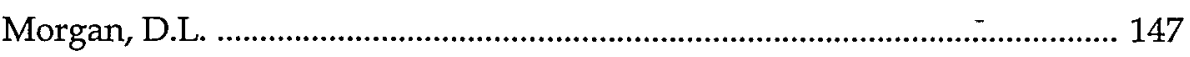

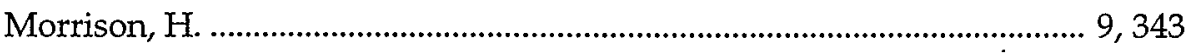

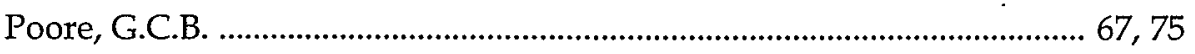

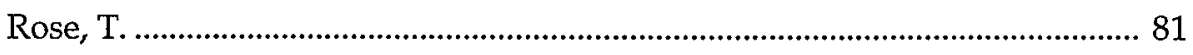

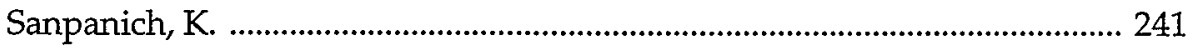

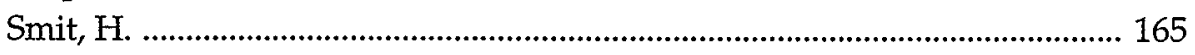

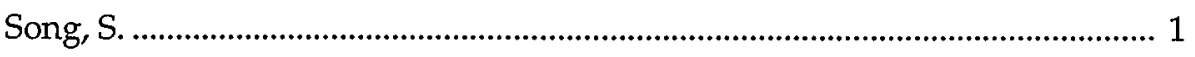

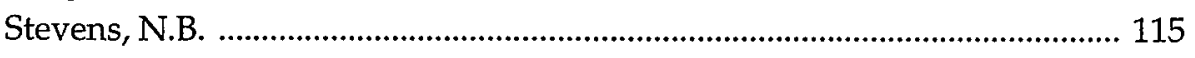

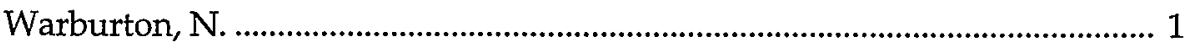

Wells, F.E. ........................................................................... 9, 81, 241, 343

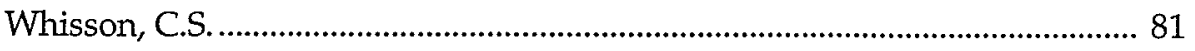

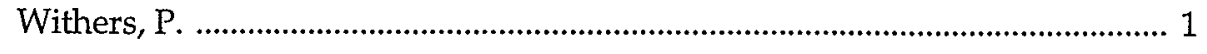

Wood, C. .

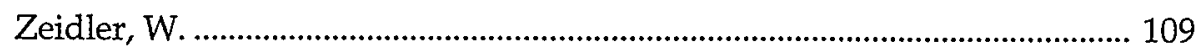




\section{Guide to Authors}

\section{Subject Matter:}

Reviews, observations and results of research into all branches of natural science and human studies will be considered for publication. However, emphasis is placed on studies pertaining to Western Australia. Longer papers will be considered for publication as a Supplement to the Records of the Western Australian Museum. Short communications should not normally exceed three typed pages and this category of paper is intended to accommodate observations, results or new records of significance, that otherwise might not get into the literature, or for which there is a particular urgency for publication. All material must be original and not have been published elsewhere.

\section{Presentation:}

Authors are advised to follow the layout and style in the most recent issue of the Records of the Western Australian Museum including headings, tables, illustrations and references.

The title should be concise, informative and contain key words necessary for retrieval by modern searching techniques. An abridged title (not exceeding 50 letter spaces) should be included for use as a running head.

An abstract must be given in full length papers but not short communications, summarizing the scope of the work and principal findings. It should normally not exceed $2 \%$ of the paper and should be suitable for reprinting in reference periodicals.

The International System of units should be used.

Numbers should be spelled out from one to nine in descriptive text; figures used for 10 or more. For associated groups, figures should be used consistently, e.g. 5 to 10 , not five to 10 .

Spelling should follow the Concise Oxford Dictionary.

Systematic papers must conform with the International Codes of Botanical and Zoological Nomenclature and, as far as possible, with their recommendations.

Synonymies should be given in the short form (taxon, author, date, page) and the full reference cited at the end of the paper. All citations, including those associated with scientific names, must be included in the references.

\section{Manuscripts:}

The original and two copies of manuscripts and figures should be submitted to the Editors, c/Publications Department, Western Australian Museum, Francis Street, Perth, Western Australia 6000. They must be in double-spaced typescript on A4 sheets. All margins should be at least $30 \mathrm{~mm}$ wide. Tables plus heading and legends to illustrations should be typed on separate pages. The desired position for insertion of tables and illustrations in the text should be indicated in pencil. Tables should be numbered consecutively, have headings which make them understandable without reference to the text, and be referred to in the text.

High quality illustrations are required to size $(16.8 \mathrm{~cm} \times 25.2 \mathrm{~cm})$ or no larger than $32 \mathrm{~cm} \mathrm{x} 40$ $\mathrm{cm}$ with sans serif lettering suitable for reduction to size. Photographs must be good quality black and white prints, not exceeding $16.8 \mathrm{~cm} \times 25.2 \mathrm{~cm}$. Scale must be indicated on illustrations. All maps, line drawings, photographs and graphs, should be numbered in sequence and referred to as Figure/s in the text and captions. Each must have a brief, fully explanatory caption. On acceptance a computer disk containing all corrections should be sent with amended manuscript. The disk should be marked with program (e.g. Word, WordPerfect, etc).

In papers dealing with historical subjects references may be cited as footnotes. In all other papers references must be cited in the text by author and date and all must be listed alphabetically at the end of the paper. The names of journals are to be given in full.

\section{Processing:}

Papers and short communications are reviewed by at least two referees and acceptance or rejection is then decided by the editors.

The senior author is sent one set of page proofs which must be returned promptly.

The senior author will receive fifty free offprints of the paper. Additional offprints can be ordered at page proof stage. 


\section{Records of the Western Australian Museum Volume 22 Part 4.2005}

\section{CONTENTS}

\section{T. Komai}

A distinctive new species of the deep-water shrimp genus Glyphocrangon

A. Milne-Edwards (Crustacea: Decapoda: Caridea: Glyphocrangonidae)

from southern Australia

H.I. Jones

The gastrointestinal nematodes of Varanus rosenbergi (Reptilia: Varanidae) and the effects of habitat change in southern Australia, with particular reference to the genus Abbreviata (Physalopteroidea)

\section{V.W. Framenau}

The wolf spider genus Artoria Thorell in Australia: new synonymies and generic transfers (Araneae, Lycosidae)

\section{Bartsch}

Lohmannella and Simognathus (Halacaridae: Acari) from Western Australia: description of two new species and reflections on the distribution of these genera

G.W. Kendrick

A new species of Bothriembryon (Mollusca: Gastropoda: Bulimulidae) from the Pliocene Roe Calcarenite, Eucla Basin, Western Australia

G.D. Edgecombe

A troglomorphic species of the centipede Cryptops (Trigonocryptops)

(Chilopoda: Scolopendromorpha) from Western Australia

\section{A.J. Bruce}

New species of Periclimenaeus Borradaile (Crustacea: Decapoda: Pontoniinae) from Ashmore Reef, North Western Australia, with remarks on $P$. pachydentatus Bruce, 1969

H. Morrison and F.E. Wells

A new species of Melo (Gastropoda: Volutidae) from northwestern Australia

T. Karanovic

Two new subterranean Parastenocarididae (Crustacea, Copepoda, Harpacticoida) from Western Australia 